\title{
The evolution of the Great Hungarian Plain fluvial system - Fluvial processes in a subsiding area from the beginning of the Weichselian
}

\author{
Tímea Kiss*, Péter Hernesz, Borbála Sümeghy, Katalin Györgyövics, György Sipos \\ University of Szeged, Department of Physical Geography and Geoinformatics, Egyetem u. 2-6, Szeged 6722, Hungary
}

\section{A R T I C L E I N F O}

\section{Article history:}

Available online $\mathrm{xxx}$

\section{Keywords:}

Paleo-hydrology

Tectonism

Paleo-direction

Great Hungarian Plain

Tisza River

\begin{abstract}
A B S T R A C T
In the Great Hungarian Plain (GHP), one of the most complex fluvial systems of Europe developed through tectonic and climatic factors and vegetation change. The aim of the present study is to summarise these controlling factors and to describe the evolution of the GHP. Special attention is paid to the latest results on late Weichselian and Holocene development in the Tisza River and their effects on the river's largest tributary: the Maros River.

Several tectonically active subsiding basins existing in the GHP have determined the direction of river courses and erosional-accumulational fluvial processes. As a result of uneven subsidence, the river's flow routes have shifted frequently. For example, the Danube and the Tisza shifted $80-100 \mathrm{~km}$, abandoning their alluvial fans where extensive aeolian processes started. Upstream from the subsiding areas, incision propagated headward, which resulted in the development of floodplain levels and terraces. Though climate and vegetation changes also simultaneously influenced the rivers' hydro-morphology, channel pattern changes were found just along the margin of the plain, and only meandering paleo-channels remained in the center of the GHP. During dry and cold periods, braided patterns appeared in the alluvial fans, most likely the result of abundant sediment supply and due to the inability of sparse riparian vegetation to stabilise the banks effectively. Based on paleo-discharge calculations, by the end of the Pleistocene the rivers of the GHP produced three to eight times more discharge than they do currently, and discharge levels continuously decreased during the Holocene. However, due to the long length of the rivers, there is a considerable time lag between the response rates of the different river sections, which makes creating paleo-hydrological reconstructions even more difficult.
\end{abstract}

() 2014 Elsevier Ltd and INQUA. All rights reserved.

\section{Introduction}

Within the Carpathian Basin, the largest intramountain basin in Europe, a fluvial system has been forming since the Late Miocene (Gábris and Nádor, 2007). The axes of the system are the Danube and Tisza Rivers. The flow directions of these rivers have changed frequently throughout the Quaternary, accumulating 300-700 m of sediment (Rónai, 1985), and leaving behind several hundred kilometers of channel fragments on the surface (Nádor et al., 2003). Though major shifts in paleo-direction are already known, as more sophisticated and greater volumes of data are available, reconstruction could be better refined. However, only the fluvial system of the Tisza River was examined in significant detail (see Borsy et al., 1989; Gábris et al., 2001, 2012; Félegyházi et al., 2004;

\footnotetext{
* Corresponding author.

E-mail address: kisstimi@gmail.com (T. Kiss).
}

Gábris and Nádor, 2007; Nádor et al., 2007, 2011; Kasse et al., 2010; Gábris, 2011; Hernesz and Kiss, 2013; Kiss et al., 2014).

Flow directions, erosion-accumulation characteristics, and channel patterns are primarily determined spatially and temporally and can in some cases demonstrate very active (up to $5 \mathrm{~mm} / \mathrm{y}$ ) tectonic movements. Movements can be defined as the relative uplift or subsidence of blocks. Subsiding areas always act as local base levels, and thus, the rivers of the Carpathian Basin and of the GHP in particular have undergone a complex evolutionary process. Other control variables, such as water and sediment discharge, grain size and channel patterns are also influenced by climatic and closely related vegetational changes. Due to the eastward increase in continental climate effects, there is a major climatic difference between the western (Transdanubia) and eastern (GHP) parts of the basin. Thus, data from different sites can vary significantly.

This study aims to consider key factors that have shaped the development of the GHP fluvial system. Special attention is paid to the Late Glacial, and the latest findings on the evolution of the Tisza 
are discussed. The study finally evaluates interactions between two large rivers and an "alluvial fan-floodplain" system within a narrow and tectonically controlled section of the Lower Tisza Region and Maros Alluvial Fan.

\section{Main factors influencing fluvial system development}

\subsection{Tectonic activity}

Weichselian fluvial development can only be interpreted by considering Tertiary and Early Quaternary tectonic changes. The evolution of the Carpathian Basin began during the Early and Mid Miocene, when the surrounding mountains were folded and uplifted (Csontos et al., 1992; Bada et al., 1999). During the late phase of the Late Miocene, subsidence triggered the transgression of the Pannonian Sea (Rónai, 1985). The sea, which had initially been connected to the Mediterranean Sea, was detached from the sea and transformed into the freshwater lake (Rónai, 1985; Horváth, 1993; Magyar et al., 1999). Since the Late Miocene, the rate of sedimentation has gradually exceeded the rate of subsidence, which has caused the open water surface to gradually disappear as fluvial processes have grown more prevalent (Juhász et al., 2004; Nádor et al., 2005). The last remnant of the lake (ca. 4.5-6.5 Ma) was located in Vojvodina, Serbia (Magyar et al., 1999; Gábris and Nádor, 2007). Throughout the Late Pliocene, the edges of the basin and the Transdanubia region were uplifted considerably as the GHP subsided (Horváth and Cloetingh, 1996; Kercsmár et al., 2012).

Tectonic movements of the Quaternary formed three major subbasins in the GHP (South Tisza Graben, Körös Basin, Jászság Basin; see Fig. 1), and several secondary subsidence areas were also active for short periods (Bereg Plain, Bodrogköz, Érmellék, Kalocsa-Baja Basin). As the intensity of the tectonic movements showed great spatial and temporal variance, subsidence rates can only be estimated via fluvial aggradation (Pécsi, 1996). As these processes occurred, certain areas subsided to a lesser degree (relative uplift) and thus acted as divides, e.g., the Danube-Tisza Interfluve or the Nyírség, which forced rivers to change direction (Borsy et al., 1989).

\subsubsection{Tectonic activity from the beginning of the Weichselian}

Throughout the Quaternary, the deepest and most dramatically subsiding basin of the GHP was the South Tisza Graben (Somogyi, 1961; Mike, 1991, Fig. 1). Located at the base level, all major rivers (e.g., Danube, Tisza) contributed to its filling. Quaternary layers are characterised by alternations of gravely sand, sand, and silty clay, and their thickness can reach 700 m (Rónai, 1985). During the Late Pleistocene, the subsidence of the graben was continuous but fluctuating (Miháltz, 1967; Mezősi, 1983; Rónai, 1985). During the Holocene, the graben's rate of accumulation has decelerated, resigning it to a very narrow zone because Early Holocene floodplain forms were not buried by younger sediments (Kiss et al., 2012a).

The Körös Basin is the second deepest basin of the GHP. The thickness of the Quaternary fluvial sediments is greater than $500 \mathrm{~m}$ (Rónai, 1985; Nádor et al., 2005, 2007; Gábris and Nádor, 2007; Kercsmár et al., 2012). Subsidence rates in the basin were until ca. $14 \mathrm{ka}$ fastest in its northern and northwestern sections. In the southern area, the rate of fluvial accumulation was only $0.5-1 \mathrm{~mm} /$ $\mathrm{y}$ by the end of the Upper Pleniglacial and Late Glacial (Nádor et al., 2007). In the eastern and southeastern rims of the Körös Basin, subsidence rates increased after the Last Glacial Maximum (Nádor et al., 2011). This may be related to similar movements in the Érmellék and Apuseni Mountains. Tectonic processes are still active in the Körös Basin and significantly influence the meander parameters of passing rivers (Petrovszki and Timár, 2010).

In the foreground of the North Hungarian Mountains, the Jászság Basin represented the centre of subsidence by the end of the

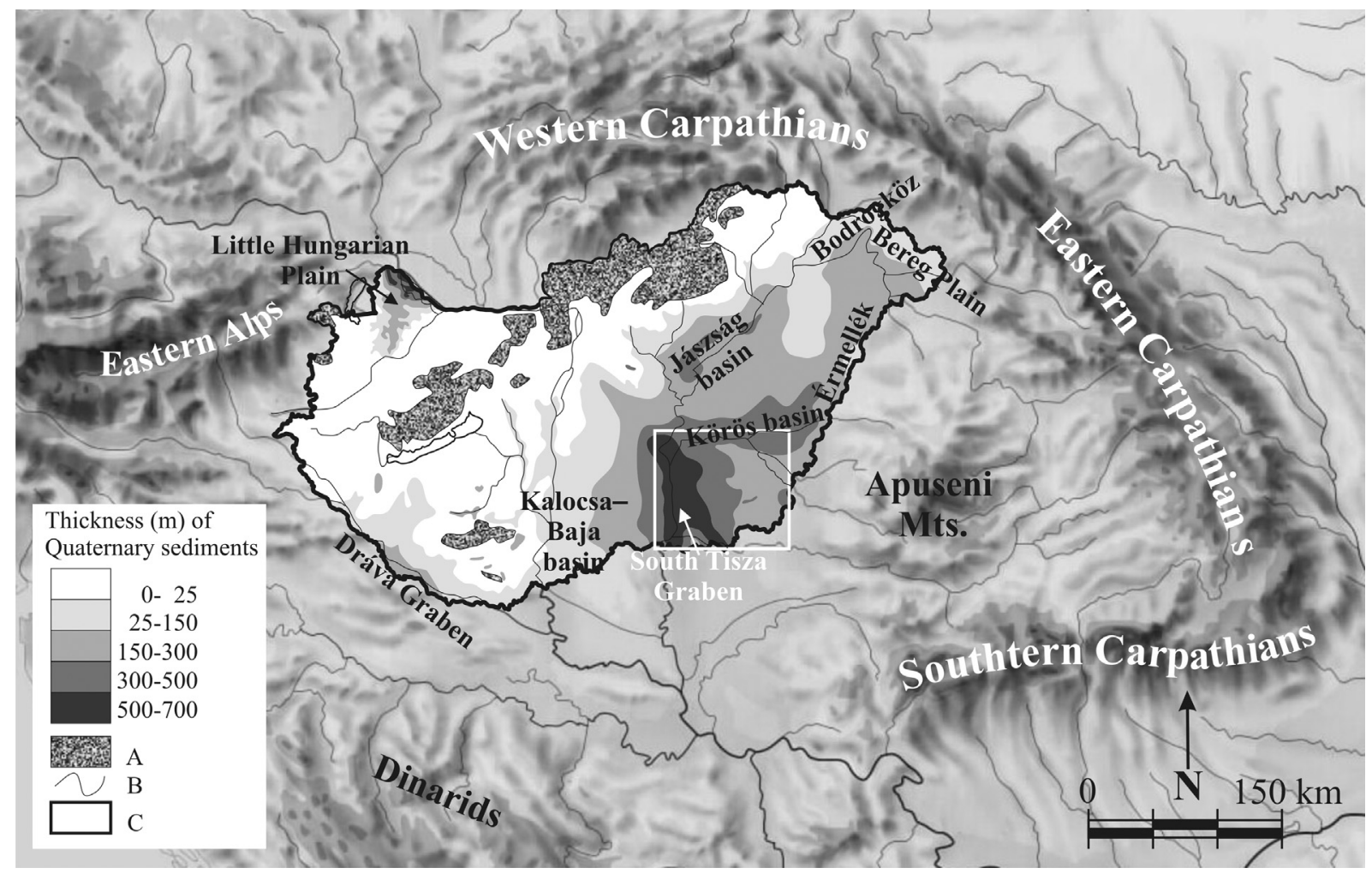

Fig. 1. Major areas of subsidence in Hungary, and the thickness (m) of Quaternary sediments. A: elevated mountains, B: present-day river system, C: study area on Fig. 4. Source: Mezősi, 2011 
Pleistocene (Gábris et al., 2001). Here, 430 m of Quaternary sediment, consisting primarily of silt and clay, was deposited while sand or gravel layers remained absent. Thus, according to Rónai (1985), the area had been a low-lying floodplain for a long period of time. However, similar to the Körös Basin, subsidence was not uniform. During low activity periods, river flows travelling from the north to the northeast merely passed through the area, while major rivers deposited fine sediments during active subsidence (Gábris and Nádor, 2007). Riverbed morphology reveals that an intensive sinking period occurred ca. $43-47 \pm 4.6 \mathrm{ka}$ when a meandering river (possibly the Paleo-Bodrog) larger than the current size of the Tisza flowed in this direction (Cserkész-Nagy et al., 2012). A similar event also occurred ca. 16.5-19 ka (Gábris and Nádor, 2007). Since the Late Glacial, the Tisza has occupied the former flow direction of the Paleo-Bodrog and has shown continuous subsidence from the end of the Pleistocene (Gábris and Nádor, 2007).

The Kalocsa-Baja Basin, which influenced the Late Pleistocene direction change of the Danube, is located along the southwestern rim of the GHP. It was most likely active during the Early Holocene as well, when the Danube eroded the Danubian Plain (Pécsi, 1996).

The subsidence of small basins in the northeastern part of the GHP (Bereg Plain and Bodrogköz) became pronounced either during the Upper Pleniglacial or at the beginning of Late Glacial (Borsy et al., 1989). During the last $32 \mathrm{ka}$, the sinking of the Bereg Plain is considered to have occurred at a rate of $0.33 \mathrm{~mm} / \mathrm{y}$ on average (Félegyházi et al., 2004). The intensive subsidence of the Bodrogköz, located just west of the Bereg Plain, began ca. 20 ka according to Borsy (1989) but only ca. 14-18 ka according to Timár et al. (2005) and Nádor et al. (2007, 2011). The spatial variability of tectonic movements is demonstrated by the difference in sediment accumulation rates between the northeastern areas and the southern and central areas, which are $0.2 \mathrm{~mm} / \mathrm{y}$ and $0.8 \mathrm{~mm} / \mathrm{y}$, respectively (Borsy, 1989).

Along the eastern rim of the GHP, the subsiding Érmellék was connected to the Körös Basin. It was active from 50 to 14 ka (Nádor et al., 2011; Kercsmár et al., 2012). Quaternary sediments are only 15-20 m thick (Rónai, 1985), denoting a very slow rate of subsidence. Though the intensity of subsidence varied over time (Thamó-Bozsó et al., 2007), it occurred simultaneously with the uplift of the neighboring Apuseni Mountains (Kercsmár et al., 2012). By the end of the Late Glacial (ca. 14-16 ka), subsidence ended, causing the Tisza to shift northward towards the sinking Bodrogköz (Nádor et al., 2007).

The subsidence of the tectonically active basins continued throughout the Holocene (with exception of the Érmellék; Joó, 1992). Currently, the greatest subsistence rates $(3-4 \mathrm{~mm} / \mathrm{y}$ ) are found in the three major sub-basins. However, compaction from intensive subsurface water, natural gas and oil exploitation may also contribute to current intensity levels (Timár, 2003). Lower rates $(1.5-2 \mathrm{~mm} / \mathrm{y})$ are found in the younger and smaller secondary basins, where the present-day sinking rate is similar to the estimations for the Quaternary.

\subsection{Climatic and vegetational changes}

Hungary was not covered by ice-sheets throughout the Pleistocene as area belonged to the periglacial zone during the cold phases. The mean annual temperature during the glacials was $10-12 \mathrm{C}^{\circ}$ lower than it is today, and katabatic winds traveling from glaciated areas brought very low levels of precipitation (summer precipitation 200-400 mm), producing a dry and cold climate (Székely, 1977; Rónai, 1985; Frenzel et al., 1992). The interglacials were characterised by a generally warm $\left(T_{\text {year }}=11-13^{\circ} \mathrm{C}\right)$ and more humid climate (Járainé-Komlódi, 2000).
Throughout the cold and dry glacials, loess steppe, subarctic grassy tundra and subarctic coniferous taiga forest covered the plains. Mountains were covered by alpine vegetation, though deciduous trees survived in some sheltered areas. During mild interstadial periods, these refugia were the source areas for the species reoccupying the basin (Járainé-Komlódi, 1997, 2000). During humid phases, forest soils developed and linear erosion occurred (Mezősi, 2011). During the coldest stadial periods, precipitation significantly decreased while loess accumulation and continuous permafrost processes were common (Székely, 1977; Pinczés, 1983; Pécsi, 1993; Fábián et al., 2014). Meanwhile, the intensity of fluvial processes decreased while frost action produced a large amount of coarse material in the valleys, leading to the formation of gravel sheets and piedmont systems (Pécsi, 1970, 1993; Székely, 1977; Pinczés et al., 1993).

During the interglacials of the Early and Middle Pleistocene, subtropical and temperate zone flora and fauna occupied the Carpathian Basin though thermophilous species disappeared rapidly when the climate turned colder. The transitional climate and diverse terrain of the basin allowed for the settlement of a wide variety of species, thus causing vegetation cover to be considerably different regionally (Járainé-Komlódi, 2000). Throughout warm and wet periods, mixed oak forests of elm and lime were widespread, and aquatic and riparian ecosystems grew richer in species. During warm but dry phases, Mediterranean-type deciduous forests prevailed (Vörös, 1987; Járainé-Komlódi, 2000). During interglacial periods, chemical weathering and karst processes intensified, fluvial activity was common, and alluvial fans and valley hillsides were eroded. Depending on precipitation levels, forest soils or chernozems developed (Székely, 1977).

\subsubsection{Weichselian (100-11.7 ka)}

The Weichselian was the coldest and driest period $\left(T_{\text {year }}=0\right.$ to $-4{ }^{\circ} \mathrm{C}, T_{\text {Jan }}=-11$ to $\left.-13^{\circ} \mathrm{C}, T_{\text {July }}=11-13.5^{\circ} \mathrm{C}\right)$ of the Pleistocene. Precipitation was very low in the basin (180-250 mm), and despite the presence of cold temperatures vegetation could not grow. As a result, diversity and density levels decreased considerably (Borsy et al., 1989).

The Weichselian was characterised by the presence of open coniferous taiga forests and steppe mosaics. Forestation during interstadial periods began in subarctic taiga regions (including pine, larch, and spruce) or mixed deciduous taiga forests (including birch, willow, oak, elm, and lime). Oak was widespread in the GHP, but similar to current conditions, significant regional differences in flora and fauna characteristics existed as a result of diverse water supply (Vörös, 1987; Járainé-Komlódi, 2000).

As the climate was extremely dry and cold during the stadial periods, steppe vegetation covered the GHP while frost-tolerant and cryophilic coniferous forests (pine, larch) grew in the mountains. The composition of vegetation in the Carpathian Basin included a mixture of eastern and western steppes (JárainéKomlódi, 2000). Willis and Van Andel (2004) described this composition as a forest-steppe resembling present-day open boreal forests dominated by pine and birch.

2.2.1.1. Upper Pleniglacial (ca. 28-14.7 ka). More data are available for the Upper Pleniglacial. However, studies have described the characteristics and timing of the Last Glacial Maximum (LGM) quite differently. Palynological results (Borsy, 1989; Willis et al., 2000; Félegyházi and Tóth, 2003) cite a cold and dry climate ca. $27-21 \mathrm{ka}\left(T_{\text {year }}=-3{ }^{\circ} \mathrm{C}, T_{\text {wint }}=-12\right.$ to $-16{ }^{\circ} \mathrm{C}, T_{\text {sum }}=11-12{ }^{\circ} \mathrm{C}$, precipitation $=180-210 \mathrm{~mm})$. According to Kasse (2002), however, the cold period lasted longer (25-15 ka) and the cooling process was more intensive $\left(T_{\text {year }}=-8^{\circ} \mathrm{C}\right)$. The LGM was followed by a mild and more humid period approximately 16.5-19 ka 
$\left(T_{\text {July }}=16-17{ }^{\circ} \mathrm{C}\right.$; Szöör et al., 1989; Sümegi and Krolopp, 1995; Sümegi and Töröcsik, 2007). Between ca. 16.5-14.7 ka, a short cold phase $\left(T_{\text {year }}=-1{ }^{\circ} \mathrm{C} ; T_{\text {July }}=13-14{ }^{\circ} \mathrm{C}\right)$ appeared, coincident with the Oldest Dryas in Northwestern Europe and GS-2a in the Greenland ice cores. The beginning of the period was reported to be quite dry (Szöőr et al., 1989; Borsy et al., 1991; Lóki et al., 1994).

During the Upper Pleniglacial, most research assumes the presence of sporadic permafrost and scarce continental steppe on the GHP but with the steppe fragmenting and tundra taking over the area during cold phases (Borsy, 1989; Lóki et al., 1995). Scattered coniferous forests mixed with deciduous trees were also present (Borsy et al., 1991; Willis et al., 2000; Willis and Van Andel, 2004), but in cold climates hygrophilous plant species were replaced by continental cold loess-steppe elements (Járainé-Komlódi, 1969; Sümegi and Krolopp, 1995; Sümegi et al., 1998, 2002, 2008; Kasse et al., 2010). During a milder phase ca. 16.5-19 ka a transition from forest-steppe to closed forest was identified (Nádor et al., 2007).

As the scarce vegetation present did not stabilise the surface effectively, either blown sand movements occurred on the terraces and alluvial fans (Lóki et al., 1995; Gábris, 2003; Félegyházi et al., 2004; Novothny et al., 2010; Gábris et al., 2012; Kiss et al., 2012b) or loess was deposited (Sümegi and Krolopp, 1995; Félegyházi and Tóth, 2003; Markovic et al., 2008; Novothny et al., 2010; ThamóBozsó et al., 2010). During milder phases, paleosoils developed on the loess (Thamó-Bozsó et al., 2010; Gábris et al., 2012).

2.2.1.2. Late Glacial (14.7-11.7 ka). The climate was less extreme throughout the Late Glacial $\left(T_{\text {year }}=-1{ }^{\circ} \mathrm{C} ; T_{\text {July }}=13-14{ }^{\circ} \mathrm{C}\right.$; Szöör et al., 1989; Lóki et al., 1995; Kasse, 2002). This period supported the final expansion of cryophilous plants (Szöör et al., 1989). Though the permafrost retreated, loess deposition was continuous (Gábris, 2003). Vegetation gradually grew denser, restricting aeolian activity (Kasse, 2002). Local sand movements have also taken place (Gábris, 2003; Novothny et al., 2010), however, and in some regions, this has even led to the development of parabolic dunes (Kiss et al., 2012b).

The beginning of the Late Glacial, the Bølling Interstadial (GIS-1e in the Greenland ice cores, see Rasmussen et al., 2006) was a generally humid and warm period $\left(T_{\text {July }}=16-20^{\circ} \mathrm{C}\right)$ that involved periodic dry spells during which permafrost could develop (Borsy et al., 1991; Sümegi and Krolopp, 1995; Nagy and Félegyházi, 2001; Gábris, 2003; Novothny et al., 2010; Gábris et al., 2011). Though steppe vegetation was dominant, shrub patches, birch forests, closed taiga and deciduous open forests also appeared (Borsy et al., 1989; Sümegi and Krolopp, 1995; Járainé-Komlódi, 2000; Gábris, 2003; Gábris et al., 2011). The aerial extension of cryophilous species decreased and was replaced with frost-tolerant and hygrophilous vegetation (Szöör et al., 1989). Blown sand territories were stabilised due to the presence of higher precipitation and colonisation by vegetation (Borsy, 1989; Gábris, 2003), and loess deposition ceased (Sümegi and Krolopp, 1995). On these stabilised surfaces, brown forest soils and organic-rich alluvial soils developed (Gábris, 2003; Novothny et al., 2010; Gábris et al., 2011).

The next phase (similar to the Older Dryas in NW Europe) was short, cold and dry $\left(T_{\text {year }}=2-3{ }^{\circ} \mathrm{C}, T_{\text {July }}=11-13{ }^{\circ} \mathrm{C}\right.$, and $T_{\text {Jan }}=-6$ to $-8{ }^{\circ} \mathrm{C}$; Járainé-Komlódi, 1969; Borsy, 1989). Consequently, vegetation grew more scarce (treeless loess steppe) and sandy surfaces were mobilised by wind at several locations (Borsy, 1989), resulting in a $2-5 \mathrm{~m}$ thick layer of sand over former, warm-period soils (Gábris, 2003).

During the second warm period of the Late Glacial (coincident with the Aller $\varnothing \mathrm{d}$ Interstadial), temperatures increased rapidly $\left(T_{\text {July }}=16-17^{\circ} \mathrm{C}, T_{\text {Jan }}=-2{ }^{\circ} \mathrm{C}\right)$ and precipitation also increased for a short time (Járainé-Komlódi, 1969; Borsy, 1989; Szöör et al., 1989;
Gábris, 2003). At that time, the Carpathian Basin was characterised by a much more continental climate than that of Northwestern or Northern Europe (Járainé-Komlódi, 2000). Vegetation grew denser and forest-steppe and pine-birch forests mixed with deciduous trees (Járainé-Komlódi, 2000). Sandy surfaces were stabilised (Borsy et al., 1991; Kasse, 2002; Gábris, 2003) and soil formation resumed (Gábris, 2003; Ujházy et al., 2003; Lóki, 2012).

Approximately $12.8 \mathrm{ka}$, a rapid and significant cooling period (similar to Younger Dryas, GS-1) took place $\left(T_{\text {year }}=5{ }^{\circ} \mathrm{C}\right.$, $T_{\text {July }}=12-14{ }^{\circ} \mathrm{C}, T_{\text {Jan }}=-4$ to $-6^{\circ} \mathrm{C}$ ) (Járainé-Komlódi, 1969; Borsy, 1989), and precipitation also decreased considerably (Borsy et al., 1991; Kasse, 2002). Vegetation grew sparse under the dry climate conditions (Borsy et al., 1991; Kasse, 2002) and some cryophilous species began to propagate (Lóki et al., 1994), although the composition of forests did not change considerably (JárainéKomlódi, 2000). These environmental conditions favoured aeolian activity (Gábris, 2003; Kiss et al., 2008, 2012b), and sand sheets covered soils (Borsy, 1989; Borsy et al., 1991) or filled up lake beds as they had done previously (Lóki et al., 1995). However, aeolian activity was not common for all sand dune areas (Novothny et al., 2010).

\subsubsection{Holocene (11.7 $\mathrm{ka}-$ )}

The Holocene began with a rapid warming period during the Preboreal Phase $\left(T_{\text {year }}=8-9{ }^{\circ} \mathrm{C}, T_{\text {July }}=18{ }^{\circ} \mathrm{C}, T_{\text {Jan }}=-2{ }^{\circ} \mathrm{C}\right.$; mean annual precipitation: $400 \mathrm{~mm}$; Járainé-Komlódi, 1969). Vegetation grew denser and forests expanded rapidly (Sümegi et al., 2008). Birch forest-steppe developed with a mixture of frost-tolerant and cryophilous species (Járainé-Komlódi, 1969, 2000; Lóki et al., 1995; Sümegi et al., 2008; Kasse et al., 2010). Later on, cryophilous elements gradually disappeared (Lóki et al., 1994). The GHP was covered with forest-steppe, while pine- and birch-dominated taiga forest mixed with deciduous trees propagated in the mountains (Járainé-Komlódi, 2000). The decrease in runoff is also demonstrated by the level of Lake Balaton, which was at its lowest during this period of the Holocene (Jakab et al., 2005). In spite of climatic warming, the decline in vegetation was not yet complete due to the presence of low precipitation, which allowed aeolian activity to appear locally (Gábris, 2003; Kiss et al., 2008; Thamó-Bozsó et al., 2010; Lóki, 2012).

The Boreal Phase was even warmer period than the previous phase $\left(T_{\mathrm{July}}=20^{\circ} \mathrm{C}, T_{\mathrm{Jan}}=0-2{ }^{\circ} \mathrm{C}\right.$, Járainé-Komlódi, 1969). Although the climate is considered to have been more humid according to some authors (Gábris, 1995), others claim that it was drier than it is currently due to the presence of regional differences (Szöör et al., 1989; Lovász, 2002). Pine trees gradually disappeared from the thermophilous deciduous forests, but as the ground-water level dropped during drought periods (e.g., in the Danube-Tisza Interfluve), forests were later replaced by steppe and forest-steppe vegetation (Járainé-Komlódi, 1969, 2000). Sand movements could still occur on drier surfaces (Gábris, 2003; Kiss et al., 2012b) while brown forest soils developed elsewhere (Gábris, 2003). The water level of lakes was approximately the same as the Holocene average or slightly lower, though marshes were present locally (Gábris, 1995). According to Szöör et al. (1989) calcareous layers formed in the lakes of the Great Plain.

The climate of the Atlantic Phase was characterised by increasing temperatures coupled with increasing humidity levels $\left(T_{\text {year }}=15-16{ }^{\circ} \mathrm{C}, T_{\text {July }}=24-25^{\circ} \mathrm{C}, T_{\text {Jan }}=4-5^{\circ} \mathrm{C}\right.$; Járainé-Komlódi, 1969). However, the temporal distribution of precipitation was not uniform as the climate was humid at the beginning of the period but then gradually grew drier (Gábris, 1995; Kiss et al., 2012b). The plains, hills, and lower regions of the mountains were covered with closed oak forests while beech dominated at higher altitudes (Járainé-Komlódi, 1969, 2000; Lovász, 2002; Sümegi et al., 2008). 
Aeolian activity declined, and thick soils developed (Gábris, 2003). Decreasing precipitation during the second half of the Atlantic phase is evident given the decrease in lake water levels that took place (Gábris, 1995; Jakab et al., 2005), which increased fluvial accumulation rates (Gábris, 1995) and reactivated aeolian activity (Gábris, 2003; Kiss et al., 2008). Moreover, this was the first period when anthropogenic disturbance (slash-and-burn agriculture by Neolithic settlers) influenced landscape development (Sümegi et al., 2002; Sümegi, 2004; Kiss et al., 2008; Gulyás and Sümegi, 2011).

During the Subboreal Phase, the climate grew cooler $\left(T_{\text {July }}=17-18^{\circ} \mathrm{C}\right.$; Nádor et al., 2007) and more humid than during the Atlantic Phase (Gábris, 1995, 2003; Sipos et al., 2010). Dense forests became widespread on the mountains and plains, and mountainous forest species appeared even along the rims of the GHP (Járainé-Komlódi, 2000; Sümegi et al., 2008). Lake water levels increased (Gábris, 1995; Jakab et al., 2005), and extensive marshes and swamps appeared (Járainé-Komlódi, 2000; Kiss et al., 2008). However, despite increased precipitation and high water levels, there is evidence of aeolian activity as a result of increasing human disturbance (Gábris, 2003; Sipos et al., 2010).

During the Subatlantic Phase, the climate grew more continental, precipitation decreased and temperatures slightly increased (Járainé-Komlódi, 2000). While oak forests were common in the GHP at this time, beech stands retreated to higher elevations (Járainé-Komlódi, 2000). Climate variations and runoff patterns are well represented with the water level changes of Lake Balaton increasing $1.4 \mathrm{ka}$ and decreasing 0.7-1.0 ka (Csernyi, 2002). Brown forest soils developed during the Medieval Warm Period when human populations were low, allowing for forestation to resume naturally (Novothny et al., 2010). However, as human activity grew more and more pronounced, the majority of the forests were cleared and land use was altered. On bare surfaces, aeolian processes occurred repeatedly (Gábris, 2003; Gábris and Túri, 2008; Kiss et al., 2008, 2012b; Novothny et al., 2010; Sipos et al., 2010).

\section{Response of rivers}

During the Neogene and the Quaternary, the flow direction and slope conditions of the river system were significantly modified by uplifts and subsidence. Moreover, climate and vegetation changes altered the system's runoff, sediment discharge and grain size traits. These changes resulted in direction changes, the development of terraces and floodplain levels, and channel pattern alterations. In this chapter, these changes in the GHP are described. The interference of these factors during the Late Glacial and Holocene periods is described in detail using the latest results on the paleohydrology of the Lower Tisza and Maros Rivers.

\subsection{Paleo-direction changes}

The aggradation of the Pannonian Lake spurred the development of the fluvial system (Somogyi, 1961, 1967; Borsy et al., 1969). Though the direction of the paleo-channels was nearly continuous in the mountainous and hilly areas, rivers changed course frequently in the Great Plain (Fig. 2) as a result of tectonic movements and sedimentation (Somogyi, 1961).

\subsubsection{Paleo-direction changes during the Quaternary prior the Weichselian}

3.1.1.1. The fluvial system of the Danube. During the Pliocene, the Danube turned south-southeast after entering the Little Hungarian Plain and reached a remnant of Pannonian Lake (Slavonian or Paludina Lake; Pécsi, 1975; Magyar et al., 1999) by flowing through West Transdanubia. Either by the end of the Pliocene (Pécsi, 1959) or during the Early Pleistocene (Ruszkiczay-Rüdiger et al., 2011), the flow direction of the Danube changed due to tectonic movements (uplift of the Keszhely-Gleichenberg divide) and shifted to the east, entering the GHP through the Visegrád Gorge (Fig. 2A; Borsy et al., 1969; Gábris and Nádor, 2007). During the Early and Middle Pleistocene periods, the Danube flowed towards the continuously subsiding South Tisza Graben. Periodic activity in the Jászság basin is also influenced its flow direction, and specifically by occasional eastward shifts of the Danube (Gábris and Nádor, 2007).

3.1.1.2. The fluvial system of the Tisza River. Leaving the Carpathians, the Tisza turned towards the continuously sinking Körös Basin (Fig. 2A) and reached the Danube near the present location of the confluence of the Tisza and Körös Rivers (Somogyi, 1967; Borsy, 1989; Gábris and Nádor, 2007). The Körös Basin was filled up cyclically with nearly $500 \mathrm{~m}$ thick sediments of the Tisza and Körös Rivers and the Maros River on occasion (Rónai, 1985; Nádor et al., 2003). As the South Tisza Graben subsided the most intensively during the Pleistocene, it attracted the Danube from the northwest and the Tisza from the northeast after leaving the Körös Basin. The fluvial system of the Bodrog-Sajó-Zagyva Rivers reached the graben from the north (Gábris et al., 2001) while the Maros River arrived periodically from the east (Kiss et al., 2014). The rivers of the GHP built extensive alluvial fans: the Danube built the DanubeTisza Interfluve, the Tisza and its tributaries formed the Nyírség, and smaller rivers (e.g., Sajó, Hernád, Maros) also deposited large sedimentary bodies (Borsy, 1989).

\subsubsection{Paleo-direction changes from the beginning of the Weichselian}

3.1.2.1. The fluvial system of the Danube. During the second half of the Weichselian, the north central part of the Danube-Tisza Interfluve was moderately uplifted, causing the Danube to shift southward (Fig. 2B; Borsy, 1989). The subsidence of the Kalocsa-Baja Basin occurring at that time also forced the Danube into this direction. Consequently, the river assumed its present north-south direction (Somogyi, 1961; Borsy et al., 1969). The increased river gradient produced incisions, leading to the development of terraces and floodplain surfaces along the Danube.

3.1.2.2. The fluvial system of the Tisza. In the beginning (Borsy, $1989)$ or the middle of the Weichselian $(46 \pm 4-39 \pm 4 \mathrm{ka}$; Thamó-Bozsó et al., 2007), the Tisza shifted eastward towards the Érmellék (Fig 2B), where it eroded a 10-15 km-wide floodplain. This direction change may be explained by (1) the slight subsidence of the Érmellék, and/or (2) the Tisza sliding off of the higher central section of its alluvial fan. From the Érmellék, the Tisza progressed towards the Körös Basin and then to the South Tisza Graben (Thamó-Bozsó et al., 2007).

According to previous reconstructions (Somogyi, 1961; Borsy et al., 1969, 1989; Mike, 1991), the tributaries of the Bodrog River also took part in the construction of the Nyírség and then joined the Tisza south of the alluvial fan. Although the Danube and the Tisza were the two main axes of the fluvial network, recent research has proven (Gábris et al., 2001; Gábris and Nádor, 2007; Cserkész-Nagy et al., 2012) that the intensified sinking of the Jászság basin during the Interpleniglacial forced the Paleo-Bodrog and its western tributaries (Sajó and Hernád Rivers, Zagyva Book etc.) to connect, forming the third main river of GHP (Gábris and Nagy, 2005). Therefore, the fluvial network was tri-axial rather than bi-axial at this time (Gábris, 2002; Gábris and Nádor, 2007).

The intensifying subsidence of the Bodrogköz and the relative uplift of the Nyírség and Érmellék regions forced the Tisza to leave the Érmellék and to turn northward (Fig. 2C). The exact timing of this avulsion is uncertain. According to Borsy et al. (1989), it 

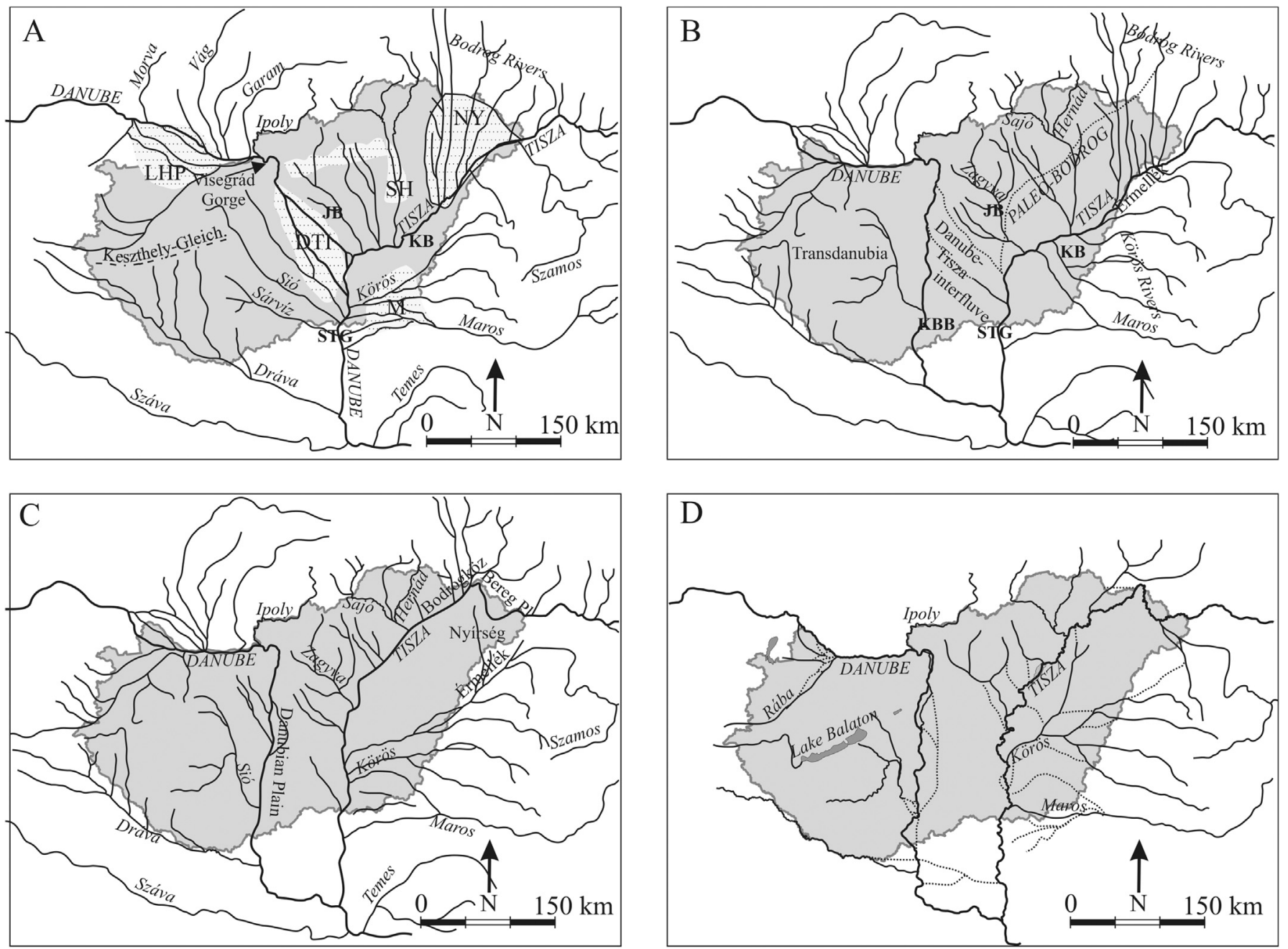

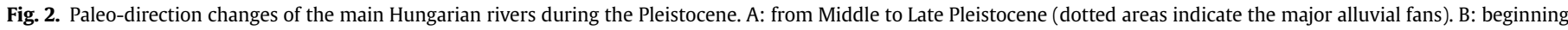

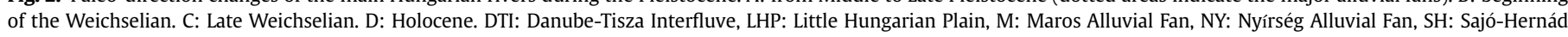
Alluvial Fan, JB: Jászság Basin, KB: Körös Basin, KBB: Kalocsa-Baja Basin, STG: South Tisza Graben.

Source: Somogyi, 1961; Gábris and Nádor, 2007; Mezősi, 2011

occurred ca. 20 ka, while Nádor et al. (2007, 2011) and Gábris and Nádor (2007) claim that it happened only ca. 14 ka. However, the latest unpublished radiocarbon data suggest the occurrence of an even younger event $11 \mathrm{ka}$. Nevertheless, when the Tisza appeared in the Bodrogköz, it captured with it all of the rivers of the PaleoBodrog system and thus fluvial processes ended as eolian activity began on the Nyírség Alluvial Fan (Kiss et al., 2012b).

From approximately $11-14 \mathrm{ka}$, the fluvial system of the GHP has been stable, and during the Late Glacial and Holocene periods only minor avulsions occurred (Fig. 2D; Somogyi, 1961; Gábris, 2011; Hernesz and Kiss, 2013). However, during this time the Maros River has almost completely reworked its alluvial fan characteristics (Somogyi, 1967; Borsy, 1989; Kiss et al., 2014).

\subsection{Incision and the development of floodplain levels}

Changes in subsidence rates, flow direction, discharge and sediment dynamics have resulted in the development of separate floodplain levels in the Great Hungarian Plain (Láng, 1960; Mezősi, 1983; Borsy et al., 1989; Gábris, 1995; Starkel, 2002). These levels are characterised by varying general heights and geomorphologic features even along the same river (Somogyi, 1967; Gábris and Nádor, 2007; Kiss et al., 2012a). According to Gábris et al. (2012), incision can occur at the beginning of any climate phase, but the process will be longer and more intensive when a dry and cold climate transitions to a humid and warm climate (e.g., terminations of glacials).

Based on recent radiocarbon data, the terrace of the Danube, which was previously thought to have been formed during the Holocene (Pécsi, 1959), is now believed to have been formed during the warm periods of the Upper Pleniglacial and Late Glacial approx. 12-19 ka (Gábris, 2006; Gábris et al., 2012). Downstream from the terrace, a $20-30 \mathrm{~km}$ wide floodplain eroded into the alluvial fan, causing the Danubian Plain to be bordered by escarpments of 5-20 $\mathrm{m}$ in height in the west (Pécsi, 1996). As a result of the incision, two floodplain levels developed along the Danube with a height difference of 2-4 m (Gábris, 2007). Though, according to Pécsi (1959), the higher floodplain formed in the beginning of the Holocene, the latest results indicate that it developed during the Late Glacial and Holocene climate shift while the lower floodplain level developed during the Subboreal phase (Gábris et al., 2012).

When the Tisza appeared on the Bereg Plain and the Bodrogköz, it incised the surface of the Nyírség Alluvial Fan, widening its floodplain via lateral erosion (Borsy et al., 1989; Vass and Szabó, 2008). Subsidence of these basins during the Late Pleistocene and Holocene caused significant sediment accumulation; however, 
there is no considerable difference between the levels of the different meander generations (Borsy et al., 1989; Szabó et al., 2012).

In the middle section of the Tisza (Middle Tisza) and along the southern edge of the Sajó-Hernád Alluvial Fan, four incision episodes occurring since the Upper Pleniglacial were identified (Gábris and Nagy, 2005; Gábris and Nádor, 2007). The highest level along the alluvial fan was formed by incision triggered by tectonism (or by climate change according to Kasse et al., 2010) during the transition from the LGM to a warm phase (ca. $19 \mathrm{ka}$ ). Subsequently, two climate-induced incisions occurred ca. 13-14 and 10.5-11.5 ka, when cold phases were overtaken by warmer periods. Finally, the lowest floodplain level was formed during a significant incision event related to tectonism at the turn of the Atlantic and Subboreal Phases (Gábris and Nagy, 2005). However, according to Kasse et al. (2010) the last major incision occurred during the Late Glacial to Holocene transition, when sediment supplies were reduced by dense vegetation growth under warmer climate conditions.

Along the Hungarian part of the lower section of the Tisza (Lower Tisza), only two floodplain levels have developed (Kiss and Hernesz, 2011). This absence of several floodplain levels may be explained by (1) continuous subsidence and accumulation (Miháltz, 1967), (2) limited space between alluvial fans, and (3) the burial or destruction of older forms. The incision began either at the beginning of the Holocene (Láng, 1960; Mezösi, 1983; Sipos et al., 2010; Kiss et al., 2012a) or during the mid-Holocene (Gábris, 1995).

\subsection{Discharge and channel pattern changes}

\subsubsection{General concepts}

Discharge is one of the most important controlling parameters of fluvial processes. Several attempts were made to establish equations to compare distinctive discharge categories (e.g., bankfull discharge: $Q_{\mathrm{bf}}$, mean discharge: $Q_{\text {mean }}$, and discharge of 1-yearreturn-interwal floods: $Q_{1}$ ) and horizontal channel parameters (e.g., chord-length, arc-length, wavelength) (see e.g., Carlston, 1965; Williams, 1984; Rotnicki, 1991). However, these relations are valid only regionally and new calculations must be created for each drainage system as environmental conditions can be significantly different. Focusing on the Pannonian Basin, Gábris (1986), Timár and Gábris (2008) and Sümeghy and Kiss (2011) created discharge equations for the meandering paleo-channels of the Tisza fluvial system. Their equations were based on the relationship between present-day discharge values and horizontal meander parameters (e.g. width, wavelength, radius of curvature), and applied for determining the paleo-discharge of Pleistocene and Holocene abandoned channels. During the investigation of braided channels in the same area a different approach was applied by Katona et al. (2012a, b), who calculated bankfull discharges of paleo-channels by using the Manning equation, which is based on cross-sectional parameters and channel slope.

Channel patterns are primarily determined by slope, discharge, vegetation, bedload grain size and bank materials (Schumm, 1985). Warm and wet periods are characterised by finer-grained transported sediments and dense vegetation, which both promote the development of a meandering pattern. In contrast, during cool and dry periods the transported sediment is coarser and sparse vegetation endorses lateral erosion of the banks, which produces wide, braided channels (Gábris et al., 2001; Kasse et al., 2010; Sümeghy et al., 2013). In general, more sediment was transported into the centre of the basin during interglacial periods due to higher discharge and transport capacities during this period than the glacial periods, when transport capacity was limited (Nádor et al., 2003). This may be explained by the distance of several hundred kilometres to the sediment source areas, which indicates a considerable temporal and spatial lag in sediment transport and the possibility that river-sections might experience different accumulational-erosional processes simultaneously (Nádor et al., 2003; Florsheim et al., 2011). Moreover, there is evidence of the simultaneous existence of meandering and braided channel patterns along the same river in extremely large discharge conditions (Sümeghy et al., 2013), suggesting that climate is not necessarily always the most important influencing on channel patterns (Nádor et al., 2005). Only meandering paleo-channels were found in the low-relief, central part of the GHP (e.g., in Bodrogköz, the Körös Basin and along the Tisza), while braided patterns appeared only in the peripheral parts, e.g., on the alluvial fans of the Sajó-Hernád and Maros Rivers, suggesting that the sediment was only coarse and abundant enough to support the development of braided sections along the rim of the GHP.

\subsubsection{Temporal evolution}

The discharge and channel pattern changes of the rivers of the GHP were studied with the greatest level of detail for the Middle Tisza Region. Here, six channel pattern changes and four incision phases have been identified since the Upper Pleniglacial (Gábris and Nagy, 2005; Gábris and Nádor, 2007; Kasse et al., 2010). However, no data exist for the Upper Tisza Region, and only limited data exist for the Lower Tisza Region (Popov et al., 2008; Kiss and Hernesz, 2011, 2012a).

The oldest superficial paleo-channel remnants date back to the Last Glacial Maximum (Fig. 3) and were identified in the Körös basin (Nádor et al., 2007). These meanders were of medium or large size $\left(R_{\mathrm{c}}=400-500 \mathrm{~m}, 50 \%\right.$ of the present radius of curvature values of the Tisza). In the Bodrogköz, meandering (possibly PaleoBodrog) channels with very small radii of curvature developed (20\% of the present values of the Bodrog; Borsy et al., 1989). During this time, braided channels formed on the Sajó-Hernád Alluvial Fan, indicating abundant sediment supplies in the peripheral areas (Gábris and Nagy, 2005). These data are in accordance with available climate and vegetation data as the period was dry and cold, which sustained the development of braided sections in the periphery of the GHP while the limited discharge supported the development of small meanders in the central areas.

In the warm last warm period of the Upper Pleniglacial (called Ságvár-Lascaux Interstadial locally; Sümegi et al., 1998), all rivers of the Great Plain followed a meandering channel pattern. The largest Tisza meanders developed in the Lower Tisza Region: they were two to three times larger than present-day channels of the area and most likely transported seven times more bankfull discharge (10 000-15 $000 \mathrm{~m}^{3} / \mathrm{s}$ ) than the Tisza does now (Hernesz and Kiss, 2013). Though some large meanders have also been preserved in the Middle Tisza Region (Gábris et al., 2012), these most likely belonged to the Paleo-Bodrog. Also during this time, meandering channels $\left(Q_{b f}=2200-2300 \mathrm{~m}^{3} / \mathrm{s}\right)$ developed on the Maros Alluvial Fan that were three times larger than present-day values (Sümeghy and Kiss, 2012). These findings are in agreement with previous results given that the interstadial was humid (Nádor et al., 2007; Sümegi and Töröcsik, 2007) and forest-steppe and closed forest spread (Nádor et al., 2007). Dense vegetation significantly decreased the intensity of lateral erosion, supporting the development of a meandering pattern.

During the last cold period (Oldest Dryas) of the Upper Pleniglacial, the paleo-meander radii of the Tisza catchment decreased, and some tributaries developed braided patterns. For example, in the Bodrogköz, the discharge was only $100-200 \mathrm{~m}^{3} / \mathrm{s}$ (ca. 5-10\% of the present values; Borsy et al., 1989). Gábris et al. (2001) identified braided paleo-channels in the Middle Tisza Region while Nádor et al. (2007) found braided and medium-sized meandering channels in the Körös Basin (their morphometric parameters are $15 \%$ of the present- 


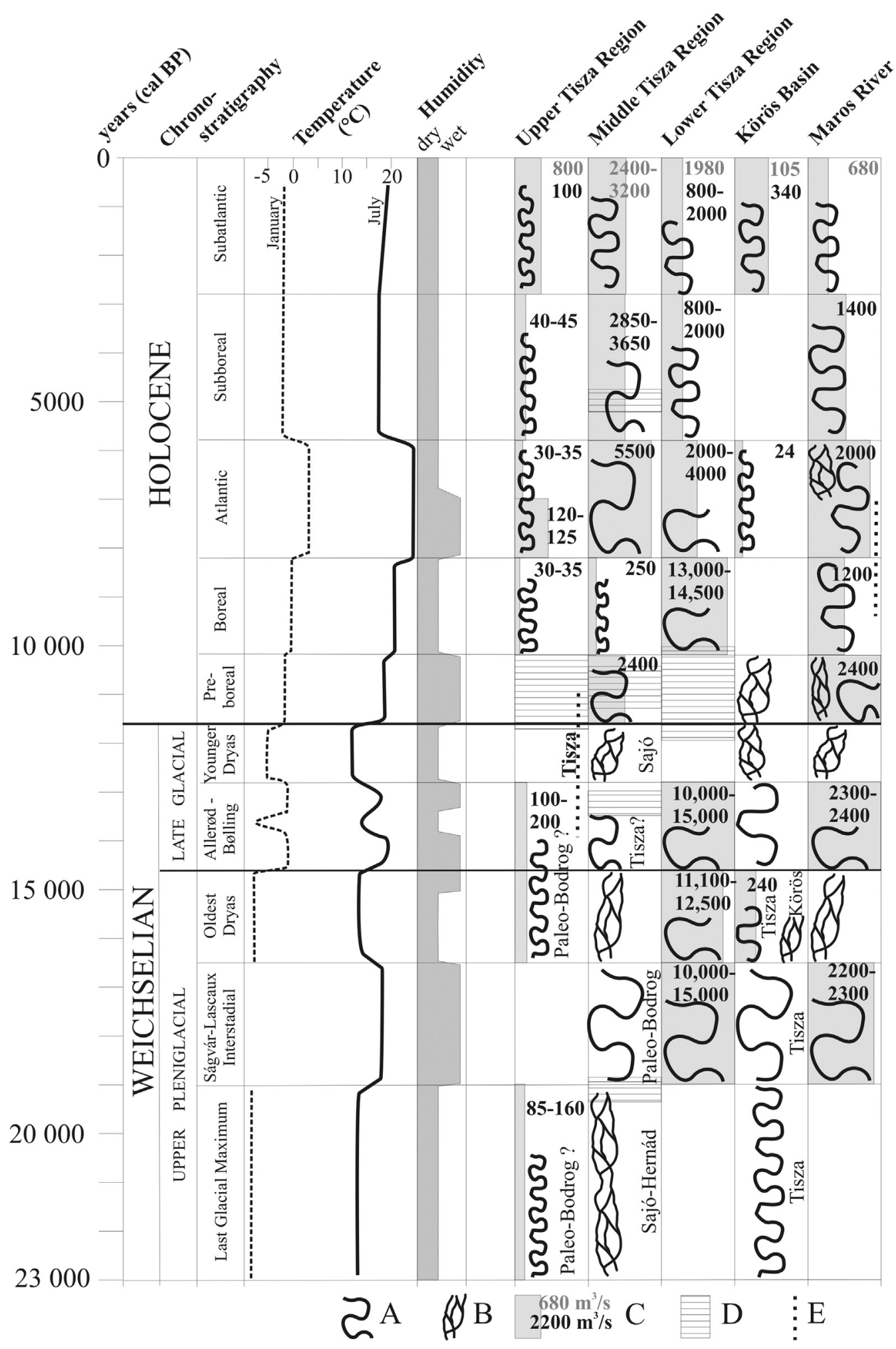

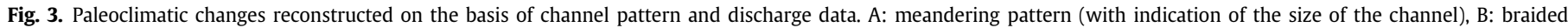

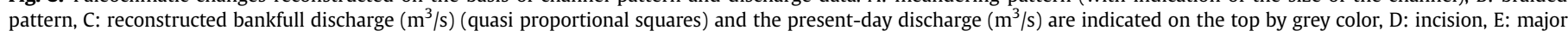
avulsion event.

Source: Borsy et al., 1989; Gábris and Nagy, 2005; Gábris and Nádor, 2007; Hernesz and Kiss, 2013; Sümeghy et al., 2013

day Tisza meanders). At the same time, the discharge of the meandering paleo-channels in the Lower Tisza Region also decreased by $10-30 \%$ (Hernesz and Kiss, 2013). This decrease in discharge is attributed to the drier and colder climate (Borsy et al., 1991).
The Late Glacial and Early Holocene are characterised by oscillations of cool/dry and warm/humid periods and steppe mixing with forest-steppe vegetation (Járainé-Komlódi, 1969; Nádor et al., 2007). Consequently, the discharge of the fluvial system also 
fluctuated. In the humid and warm periods of the Late Glacial nearly all of the rivers followed a meandering pattern. While in the Bodrogköz, meander patterns remained small as they had been previously (Borsy et al., 1989), large bends developed along the Middle and Lower Tisza and in the Körös Basin. For example, the $Q_{b f}$ of the Lower Tisza was $10000-15000 \mathrm{~m}^{3} / \mathrm{s}$, which is $10-30 \%$ greater than it was previously and 12-15 times greater than it is at present (Mezősi, 2011; Hernesz and Kiss, 2013). At the same time, the discharge of the meandering Maros slightly decreased $\left(2000-2200 \mathrm{~m}^{3} / \mathrm{s}\right)$ but was still three times greater than it is today (Sümeghy et al., 2013). This widespread, meandering pattern can be attributed to the dense vegetation and steady regime that had resumed at that time. However, the differences in discharge also reflect considerable environmental variability, e.g. geological background, climatical and vegetational differences resulting in considerable run-off differences within the sub-catchments, as is the case currently (Andó, 2002).

At the end of the Late Glacial a short, cold and dry period appeared, when multiple channel systems developed on the Sajó-Hernád and Maros Alluvial Fans and in the Körös Region (Nagy and Félegyházi, 2001; Nádor et al., 2007; Sümeghy and Kiss, 2012). The braided pattern appearance was the combined result of sparse vegetation in the area (Kasse et al., 2010) and the short distance to sediment sources.

The Preboreal Phase was characterised by medium- and smallsize meanders that were similar to the present-day meanders that have developed in the Middle Tisza Region (Gábris et al., 2001, 2012). The Körös had a braided pattern (Nádor et al., 2007) while meandering and braided channels coexisted along the Maros Alluvial Fan. At this time, the bankfull discharge of the Maros $\left(2000-3000 \mathrm{~m}^{3} / \mathrm{s}\right)$ was three to four times greater than it is now (Sümeghy and Kiss, 2012; Katona et al., 2012a,b). The quasi synchronism of the meandering and braided patterns may be explained by the gradual spread of forest steppe and by considerable environmental variations within the sub-catchments, which produced different run-off and sediment discharge values.

Since the Boreal Phase, several paleo-channels have been preserved along the Tisza and Maros Rivers. In accordance with previous climate and vegetation data, the discharge value for these rivers was smaller than it is at present. Based on the calculations of Gábris (1986), the $Q_{\text {mean }}$ of the Upper Tisza was only $30-35 \mathrm{~m}^{3} / \mathrm{s}$ (4-5\% of the present mean discharge) while it was $250 \mathrm{~m}^{3} / \mathrm{s}$ on the Middle Tisza (25-30\% of the present value). However, on the lower floodplain of the Lower Tisza River, large meanders $\left(Q_{b f}=13.0-14.5\right.$ thousand $\mathrm{m}^{3} / \mathrm{s}$ ) were found downstream from the Tisza-Maros confluence. This supports the idea of sub-catchments of different degree of activity, caused mainly by the difference in their climatic characteristics, namely catchment exposure to westerly winds and Mediterranean cyclones. These influence fundamentally the timing and magnitude of floods, and channel processes, as it has been experienced during previous flood events (Vágás, 1982; Andó, 2002). For example, concerning subcatchments opened to the west (e.g. Maros, Körös) largest floods will occur at early spring when westerly airflow intensifies and snow-melt is usually accelerated by heavy rains. On the other hand, concerning catchments opened to the south (e.g. Hernád, Sajó) extreme floods will rather develop as a matter of early summer heavy rainfalls caused by Mediterranean cyclones (Kiss et al., 2013). Beside exposure other factors, such as the shape of the catchment, its geology, general slope conditions, and vegetation can also influence the run-off conditions.

Because the beginning of the Atlantic Phase was humid, discharge levels increased along the Tisza. In the Upper Tisza Region, large meanders $\left(R_{\mathrm{c}}=500 \mathrm{~m}\right)$ four to five times larger than those from the end of the Boreal Phase developed (Borsy et al.,
1989). In the Middle Tisza Region, the Tisza had a $Q_{\text {mean }}$ of $5520 \mathrm{~m}^{3} / \mathrm{s}$ (Gábris, 1986), which is ca. 20 times greater than previous value (and ten times greater than the present-day value). Though the Maros possessed both braided and meandering paleochannels, the braided pattern may have resulted from a slope increase caused by avulsion. The meandering channel produced two to three times more discharge than modern values $\left(Q_{b f}=2000 \mathrm{~m}^{3}\right)$ s; Sümeghy and Kiss, 2012). These data are closely aligned with the latest paleo-environmental results (Gábris, 1995; Kiss et al., 2012b).

Subboreal and Subatlantic meander fragments are only preserved in close proximity to the present Tisza River. No distinct river courses can be identified, and these periods therefore cannot be analysed separately. Over the past $5 \mathrm{ka}$, rivers of the GHP have followed a meandering pattern. The limited amount of existing data suggests that compared to the Atlantic Phase, the discharge decreased by $\sim 50 \%$ in both the Middle Tisza $\left(2850-3650 \mathrm{~m}^{3} / \mathrm{s}\right)$ and Körös Rivers (Gábris, 1986). This can be explained by a decrease in runoff, which resulted from the advance of closed forests and relatively steady runoff levels. The Maros, however, followed two well-defined paleo-courses during this period and thus provides data useful for reconstructing Late Holocene paleo-hydrological changes. Discharge during the Subboreal Phase decreased by $30 \%$ $\left(Q_{b f}=1400 \mathrm{~m}^{3} / \mathrm{s}\right)$ compared to the Atlantic Phase values, and a further $50 \%$ decrease $\left(Q_{b f}=680 \mathrm{~m}^{3} / \mathrm{s}\right)$ can be suggested during the Subatlantic Phase. Lower runoff values can be explained by decreasing precipitation during this period (Lovász, 2002; Kiss et al., 2014). This relationship is also supported by the calculations of Nováky (1991), who found that $\pm 5 \%$ precipitation change as a matter of present day global warming can result in $\pm 10-30 \%$ runoff change on a sub-catchment of the Tisza (Zagyva River).

\subsection{Late Weichselian-Holocene course changes in the Lower Tisza Region and in the adjacent Maros Alluvial Fan}

The Lower Tisza Region and the Maros Alluvial Fan offer a unique opportunity for paleohydrological reconstruction. The dynamic interaction between two large rivers and the operation of an "alluvial fan-floodplain" system can be studied within a confined and tectonically controlled space. Between the alluvial fans of the Danube and Maros, a fairly narrow (5-10 km) floodplain developed (Fig. 4), although, for example, the common floodplain of the Tisza and Körös Rivers in the Middle Tisza Region is $90-100 \mathrm{~km}$ wide. The area is under strong tectonic control as the South Tisza Graben subsided extensively during the Quaternary. Therefore, all of the major rivers of the GHP (i.e., Danube, Tisza, Bodrog, Körös and Maros) flowed at one time into this area (Somogyi, 1961, 1967; Borsy et al., 1969; Rónai, 1985; Gábris and Nádor, 2007), destroying former fluvial forms. By the end of the Pleistocene and during the Holocene, only the Tisza and Maros shaped the area, as the Danube had already left the region (Somogyi, 1961; Borsy, 1989).

To reconstruct the Late Pleistocene and Holocene development of the Tisza floodplain and the Maros alluvial fan, geomorphological and sedimentological analyses were carried out on paleochannels and floodplain islands (Kiss and Hernesz, 2011; Sümeghy and Kiss, 2012; Kiss et al., 2012a; Hernesz and Kiss, 2013; Kiss et al., 2014). The oldest and youngest point-bars of the paleo-meanders were dated via OSL measurement. The bankfull discharge of the paleo-meanders was calculated based on regional equations (Sümeghy and Kiss, 2011).

The oldest paleo-channel in the region was identified in the centre of the Maros alluvial fan. After leaving the Lipova Gorge, it flowed north and then southwest (Fig. 4A, a drainage direction). The channel was active from $18.7 \pm 2.3 \mathrm{ka}$ to $16.3 \pm 1.9 \mathrm{ka}$. The river followed a meandering channel pattern $\left(Q_{b f}=2200 \mathrm{~m}^{3} / \mathrm{s}\right)$ and carried three times the discharge than is carries at present. These 


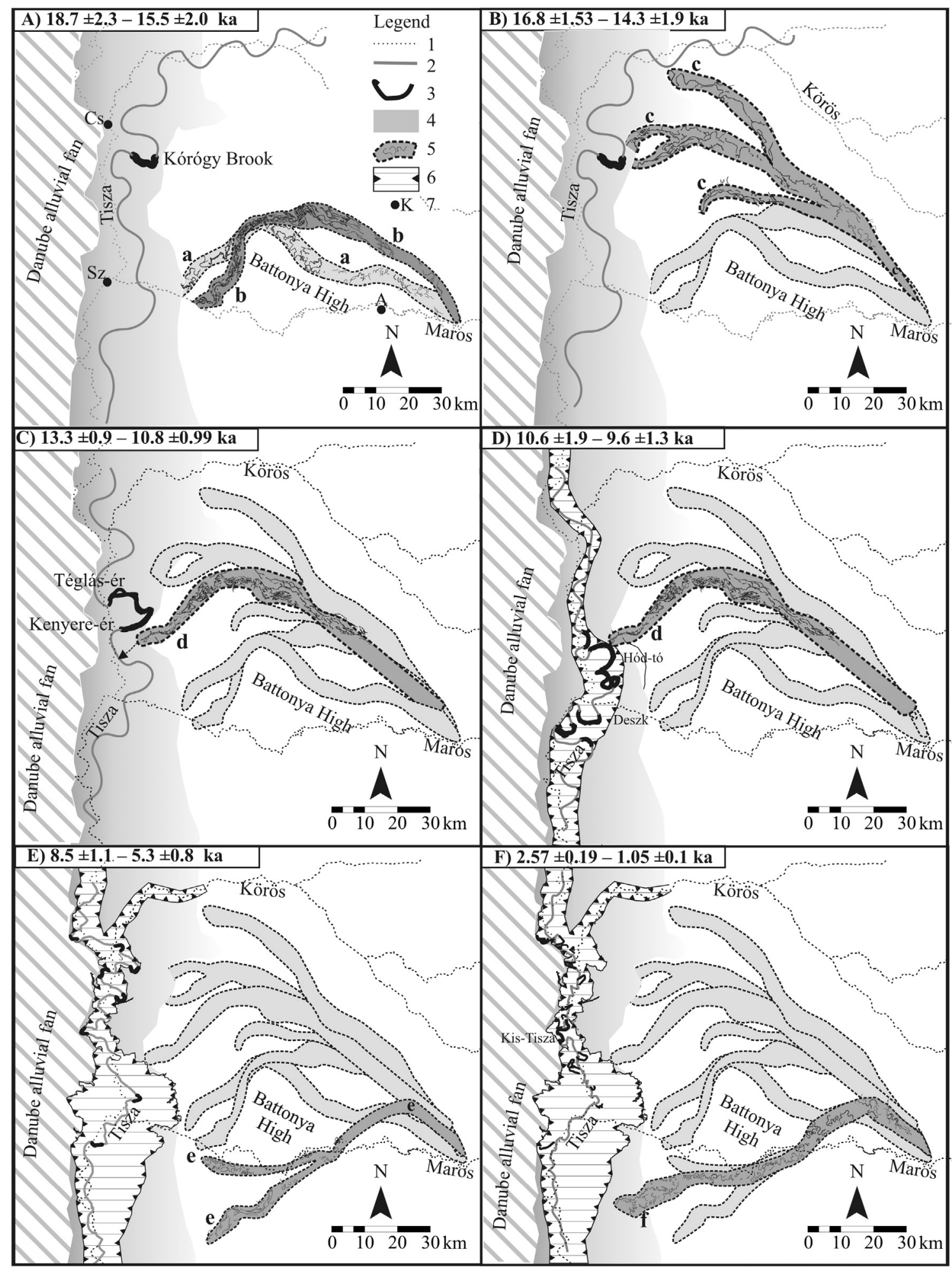

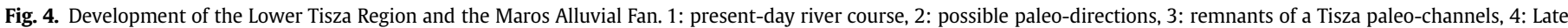
Pleistocene floodplain, 5: paleo-channel zone (a-f) of the Maros, 6. Holocene floodplain and its eroded rim. 7. Towns: Cs: Csongrád, Sz: Szeged, A: Arad, K: Kikinda.

high values can be explained by the existence of a warm and humid climate at the end of the Upper Pleniglacial, when large meanders were also formed along the Upper Tisza (Gábris and Nádor, 2007).

Two other identifiable paleo-channel directions $(b-c)$ occurred in the alluvial fan since the Late Glacial, though their activities overlap. The proximal reach of a braided paleo-drainage active ca.
$15.5 \pm 2.0$ ka ago shifted northward then turned sharply southwest, passing the Battonya High and partially destroying the previous channel (Fig. 4A, b drainage direction). This enormous channel (width: $1.8-4.4 \mathrm{~km}$ ) merged with the Tisza in roughly the same site as the present-day location of the Tisza-Maros confluence. The paleo-channel developed under the last dry and cold phase of the 
Upper Pleniglacial, which was characterised by increased coarse sediment production and sparse steppe vegetation.

Approximately $15.2 \pm 2.0-14.3 \pm 1.9 \mathrm{ka}$, the Maros possessed three simultaneously active courses (or very rapid avulsions) flowing in a northwest direction and even reaching the Körös Basin (Fig. 4B, c drainage direction). The presence of such meandering and anastomosing channels of similar age indicates a considerable bankfull discharge value $\left(2500-3000 \mathrm{~m}^{3} / \mathrm{s}\right)$. The channels may have developed during the warm and humid phase of the Late Glacial, when run-off increased but vegetation could successfully prevent intensive lateral erosion, facilitating the appearance of a meandering pattern.

When the Maros occupied the northern and northeastern part of its alluvial fan, the Tisza formed its higher floodplain (Fig. 4A-B). Only one paleo-meander fragment remained from this period (Kórógy Brook: $16.8 \pm 1.53 \mathrm{ka}$ ), and it was a large meander that drained $11100-12500 \mathrm{~m}^{3} / \mathrm{s}$ of water at the bankfull stage. The Maros most likely contributed to this large value as it merged with the Tisza either in the northern part of the area or in the Körös Basin. While the Tisza followed a meandering channel, the Maros was characterised by meandering and anastomosing patterns. This denotes the existence of differences in sediment discharge even within the same period.

The paleo-Maros shifted to the central section of the alluvial fan $12.4 \pm 2.1 \mathrm{ka}$ ago and formed a well-defined course (Fig. 4C, D, d drainage direction). The pattern of this channel was anastomosing at the apex of the alluvial fan, braided and then meandering in the distal part of the fan, and then braided again along the rim. This spatial variability can be explained the presence of differing slope conditions (Katona et al., 2012a,b), discharge changes on the alluvial fan due to infiltration and upwelling (Rachocki, 1981), and in part by the scarce and patchy vegetation of the Late Glacial (Borsy et al., 1989; Járainé-Komlódi, 2000; Gábris, 2003). According to the meandering sections, its $Q_{b f}$ was $2655 \mathrm{~m}^{3} / \mathrm{s}$. Because misfit channels also developed $\left(12.9 \pm 1.4-11.4 \pm 1.7 \mathrm{ka}, Q_{b f}=500 \mathrm{~m}^{3} / \mathrm{s}\right)$ at this time in an older drainage, discharges must be summed, which results in an extremely high $\left(Q_{b f}=3200 \mathrm{~m}^{3} / \mathrm{s}\right)$ value for the Late Glacial and Holocene transitional period.

Coeval paleo-meanders of the Tisza are located along both the higher and lower floodplains. The channels on the higher floodplain (Kenyere Brook: $13.3 \pm 0.9-10.8 \pm 0.9$ ka; Sipos et al., 2010; Téglás Brook: $12.21 \pm 1.53 \mathrm{ka}$ ) were located upstream from the Tisza-Maros confluence (Fig. 4C). Only silty-clay sediments were found at the bottom of these Tisza meanders, indicating a suspended sediment-dominated transport system that is most likely in connection with loess formation and erosion in the catchment (Kasse et al., 2010). The absence of sandy bedload sediments also supports the notion that the confluence occurred further downstream as the Maros carried coarser sediments. The discharge of these Late Glacial Tisza channels implies significant runoff $\left(Q_{b f}=10000-15000 \mathrm{~m}^{3} / \mathrm{s}\right)$. While the flow direction of the Maros was stable for several thousands of years during this period, tectonic movements significantly influenced the development of the Tisza. Thus, within a relatively short time (ca. 10-12 ka ago), the Tisza incised into its floodplain and created a new, lower floodplain level (Fig. 4D). The incision was driven by subsidence processes that began in the southern part of the South Tisza Graben. This subsidence increased the steepness of the slope, causing headward erosion to begin developing divergent floodplains and meander cores (Umlaufberge). The height difference between the high and low floodplain levels, representing pre- and post-subsidence floodplains, is $6.3-7.5 \mathrm{~m}$ near the Danube-Tisza confluence and decreases to $3.7-4.8 \mathrm{~m}$ in the northern part of the Lower Tisza Region (Körös-Tisza confluence). The umlaufbergs show sharper and less-eroded rims in the north than in the south, demonstrating a northward decrease in age (Kiss et al., 2012a). Thus, the incision could be understood as an aggression wave (see Brunsden, 2001) that propagates upstream with an increasing time lag between subsidence processes and responses along the river network. This conclusion is supported by our preliminary OSL dating results on paleo-channels in Vojvodina. Here, paleo-channels along the same floodplain level are ca. $9.6 \mathrm{ka}$ and are younger northward (ca. $8.9 \mathrm{ka}$ ).

Along the lower floodplain level, large paleo-meanders were preserved (Hód-tó: $W=600 \mathrm{~m} ; R_{\mathrm{b}}=3600 \mathrm{~m}$; Deszk: $W=500 \mathrm{~m}$; $R_{\mathrm{b}}=2800 \mathrm{~m}$ ) and the Maros ran directly into one of these while its d-paleo-drainage was active. Therefore, downstream from the confluence the Tisza possessed larger meanders (at Deszk $=10.6 \pm 1.9-8.0 \pm 0.7 \mathrm{ka}$, Sipos et al., 2010) that drained a considerable amount of water $\left(Q_{b f}=13000-14500 \mathrm{~m}^{3} / \mathrm{s}\right)$. As the size and discharge of the Maros and Tisza paleo-channels did not change considerably at the beginning of the Holocene, this suggests that (1) the effect of the climate shift was buffered by vegetational changes, and (2) the incision of the Tisza was not caused by increasing discharge as was believed earlier but primarily by tectonic processes (Somogyi, 1967; Mezősi, 1983).

A major avulsion occurred in the Maros alluvial fan during the Holocene, and $8.5 \pm 1.1$ ka the river shifted to the southern part of the fan, passing the Battonya High from the south (Fig. $4 \mathrm{E}$, e drainage direction). This change may be driven by the same tectonic subsidence process, which initiated the development of the lower floodplain of the Tisza. The channel that formed after the avulsion (Lovrin: $7.1 \pm 1.1 \mathrm{ka}$ ) most likely developed a braided pattern $\left(Q_{b f}=1970 \mathrm{~m}^{3} / \mathrm{s}\right.$; Katona et al., 2012a,b) as a result of the increase in slope as environmental conditions did not support braiding during the Atlantic Phase. A slightly younger $(6.1 \pm 1.1-3.5 \pm 0.4 \mathrm{ka})$ meandering paleo-channel $\left(Q_{b f}=2000 \mathrm{~m}^{3} /\right.$ s) shifted northwards. While these paleo-directions of the Maros were active, the Tisza-Maros confluence was located $10-60 \mathrm{~km}$ south of its current location. Thus, the common increased discharge of the two rivers combined with the increase in slope led to the widening of the lower floodplain in the south (in Vojvodina). North of the confluence, the mid-Holocene meanders of the Tisza are located farther from the present-day river, and they are smaller $\left(R_{\mathrm{b}}=700-1200 \mathrm{~m}, W=190-300\right)$ than Early Holocene channels (e.g., Deszk, Hód-tó), reflecting a decrease in bankfull discharge (to $2000-4000 \mathrm{~m}^{3} / \mathrm{s}$, by $70-80 \%$ ). This value is greater than that of the Maros (30\%), reflecting distinct activity in the catchments.

The youngest identifiable paleo-drainage event that occurred in the Maros is only $1.6 \pm 1.3 \mathrm{ka}-1.9 \pm 0.3 \mathrm{ka}$, and it ran nearly alongside the present-day river course with the exception of turning southwest at the distal section of the alluvial fan and reaching the Tisza $\sim 50 \mathrm{~km}$ south of the present-day confluence (Fig. 4F, f drainage direction). Given its size, this channel reflects decreased discharge $\left(Q_{b f}=1400 \mathrm{~m}^{3} / \mathrm{s}\right)$ but is still higher than the modern value $\left(680 \mathrm{~m}^{3} / \mathrm{s}\right)$. The Maros occupied its present course in the centre of the alluvial fan overtime. During the Subatlantic Phase, small paleo-meanders developed in close proximity to the location of the present-day Tisza $\left(Q_{b}=600-1100 \mathrm{~m}^{3} / \mathrm{s}\right)$. Data indicating a channel shift $360 \pm 40$ y ago suggest that small avulsions developed until they were regulated. The fact that the channel fragments are becoming younger as they draw closer to the active Tisza suggests that the Tisza is growing more confined to the South Tisza Graben axis, which in turn reflects its increasing tectonic activity.

\section{Conclusions}

The fluvial development of the Carpathian Basin and the GHP, having been influenced by Quaternary climate changes, climatedriven vegetational changes, and spatial and temporal variations 
in tectonic movements, is rather complex. Rivers have changed course considerably in response to uneven subsidence processes. For example, the Danube shifted $\sim 100 \mathrm{~km}$ westward in the development of its present-day course, and the Tisza shifted $\sim 80 \mathrm{~km}$ when it left the Érmellék and flowed to the Bodrogköz. These changes fundamentally altered the landscape development of the areas in which the rivers arrived (typically causing an increase in the river the slope that led to incisions and the development of floodplains and terraces) as well as the regions that they had abandoned (the development of misfit channels and dry surfaces that support aeolian activity). The effect tectonic activity often surpassed the effect of climatic control on rivers as channel pattern changes (e.g., Maros) and incisions (e.g., Tisza) can occur without climate change.

The historical development of the GHP is even more complex if we consider the notion that the different tectonic activities in the subsiding basins resulted in spatially and temporally varied erosional and accumulational fluvial responses. The time lag identified between disturbances and responses along the river network further complicated paleo-hydrological reconstructions.

Based on paleo-discharge calculations, the rivers of the GHP were by the end of the Pleistocene producing three to eight times more discharge than they produce currently, and these discharge levels continuously decreased throughout the Holocene. However, as no considerable discharge change occurred during the transition from the Late Glacial to the Holocene, it is difficult to evaluate the hydro-morphological response of rivers to this event. Moreover, during the Pleistocene-Holocene transition, tectonic activity, the leading force behind fluvial processes, was identified at certain locations (e.g., Kalocsa-Baja Basin, South Tisza Graben).

Though the larger rivers in the centre of the GHP followed meandering pattern throughout the Late Pleistocene and Holocene, tributaries frequently changed channel patterns along their alluvial fans, and very often independently of climate change. These channel pattern characteristics may be explained by the presence of long transport distances as most of the coarse sediment was deposited in the steeper alluvial fans and primarily finer sediment was transported towards the centre of the plain.

During the last several decades, great advances in Hungarian paleo-hydrological research have resulted in new techniques that enable the development of more detailed reconstructions (Nagy, 2002; Gábris and Nádor, 2007; Kasse et al., 2010; Nádor et al., 2011; Gábris et al., 2012; Kiss et al., 2014). These techniques revealed that the Holocene was more "eventful" than was believed earlier. For example, in the Maros alluvial fan, only one Holocene channel change was believed to have occurred previously (Borsy, 1989; Gábris, 2003), and now, it appears that several changes occurred during this period (Sümeghy et al., 2013; Kiss et al., 2014).

\section{Acknowledgements}

We are grateful for the revisions and useful comments provided by Professor Gyula Gábris. The research was sponsored by the OTKA-83455, MTA Bolyai János research fellowship, HURO/1101/ 126 ENVIARCH and TÁMOP 4.2.4.A/2-11-1-2012-0001 funds.

\section{References}

Andó, M., 2002. A Tísza vízrendszer hydrogeográfiája (Hydrogeography of the Tisza System). SZTE-TFGT, Szeged, 168. (in Hungarian).

Bada, G., Horváth, F., Fejes, I., Gerner, P., 1999. Review of the present-day geodynamics of the Pannonian basin: progress and problems. Journal of Geodynamics $27,501-527$.

Borsy, Z., 1989. Az Alföld hordalékkúpjainak negyedidőszaki fejlődéstörténete (Quaternary evolution of the alluvial fans of the Alföld). Földrajzi Értesítő 38, 211-224 (in Hungarian).
Borsy, Z., Félegyházi, E., Csongor, É., 1989. A Bodrogköz kialakulása és vízhálózatának változásai (Development of the Bodrogköz and its paleodrainage changes). Alföldi Tanulmányok 13, 65-81 (in Hungarian).

Borsy, Z., Félegyházi, E., Hertelendi, E., Lóki, J., Sümegi, P., 1991. A bócsai fúrás rétegsorának szedimentológia - palynologiai - malakofaunisztikai vizsgálata (Sedimentological, palynological and malacological study of the Bócsa drilling). Acta Geographica ac Geologica et Meteorologica Debrecina 28-29, 263-277 (in Hungarian).

Borsy, Z., Molnár, B., Somogyi, S., 1969. Az alluviális medencesíkok morfológiai fejlödéstörténete (Evolution of the Hungarian alluvial basins). Földrajzi Közlemények 17, 237-254 (in Hungarian).

Brunsden, D., 2001. A critical assessment of the sensitivity concept in geomorphology. Catena 42, 99-123.

Carlston, C.W., 1965. The relation of free meander geometry to stream discharge and its geomorphic implications. American Journal of Science 262, 864-885.

Cserkész-Nagy, Á., Thamó-Bozsó, E., Tóth, T., Sztanó, O., 2012. Reconstruction of a Pleistocene meandering river in East Hungary by VHR seismic images, and its climatic implications. Geomorphology 153-154, 205-218.

Csernyi, T., 2002. A balatoni negyedidőszaki üledékek kutatási eredményei (Quaternary sediments of the Lake Balaton). Földtani Közlöny 132, 193-214 (in Hungarian).

Csontos, L., Nagymarosy, A., Horváth, F., Kovac, M., 1992. Tertiary evolution of the Intra-Carpathian area: a model. Tectonophysics 208, 221-241.

Fábián, Sz., Kovács, J., Varga, G., Sipos, Gy., Horváth, Z., Thamó-Bozsó, E., Tóth, G. 2014. Distribution of relict permafrost features in the Pannonian Basin Hungary. Boreas 43, 722-732.

Félegyházi, E., Szabó, J., Szántó, Zs, Tóth, Cs, 2004. Adalékok az északkelet-Alföld pleisztocén végi, holocén felszínfejlődéséhez újabb vizsgálatok alapján. (Late Pleistocene and Holocene evolution of NE Great Plain) II. MFK Szeged, 1-10. (in Hungarian).

Félegyházi, E., Tóth, Cs, 2003. A Halas-fenék leföződött medermaradvány üledékanyagának szedimentológiai és palinológiai vizsgálata (Sedimentological and palynological analysis of the Halas ox-bow). Acta Geographica ac Geologica et Meteorologica Debrecina 36, 21-30 (in Hungarian).

Florsheim, J.L., Pellerin, B.A., Oh, N.H., Ohara, N., Bachand, P.M., Bachand, S.M., Bergamaschi, B.A., Hernes, P.J., Kavvas, M.L., 2011. From deposition to erosion: spatial and temporal variability of sediment sources, storage, and transport in a small agricultural watershed. Geomorphology 132, 272-286.

Frenzel, B., Pécsi, M., Velichko, A., 1992. Atlas of the Paleoclimates and Paleoenvironment of the Northern Hemishere. MTA FKI-Fischer, Budapest.

Gábris, Gy, 1986. Alföldi folyóink holocén vízhozamai. (Holocene discharge of the rivers of the Great Plain). Alföldi Tanulmányok 10, 35-48 (in Hungarian).

Gábris, Gy, 1995. A folyóvízi felszínalakítás módosulásai a hazai későglaciális-holocén öskörnyezet változásainak tükrében (River activity as a function of changing palaeoenvironmental conditions during the Late Glacial-Holocene, Hungary). Földrajzi Közlemények 119, 3-10 (in Hungarian).

Gábris, Gy, 2002. A Tisza helyváltozásai (Changes of Tisza River). In: Mészáros, R. Schweitzer, F., Tóth, J. (Eds.), Jakucs László, a tudós. MTA-FKI Pécs, pp. 91-105 (in Hungarian).

Gábris, Gy, 2003. A földtörténet utolsó 30 ezer évének szakaszai és a futóhomok mozgásának föbb periódusai Magyarországon (Periods of the last 30 thousand years and aeolian sand movements). Földrajzi Közlemények 127, 1-14 (in Hungarian)

Gábris, Gy, 2006. A magyarországi folyóteraszok kialakulásának és korbeosztásának magyarázata az oxigénizotóp-sztratigráfiai tükrében (Formation and chronology of the Hungarian river terraces in the light of oxygen isotope stratigraphy). Földrajzi Közlemények 130, 123-133 (in Hungarian).

Gábris, Gy, 2007. Kapcsolat a negyedidőszaki felszínalakító folyamatok időrendje és zz oxigénizotóp-rétegtan között - magyarországi lösz-paleotalaj-sorozatok és folyóvízi teraszok példáján (Quaternary surface processes and oxygen isotope stratigraphy - examples on loess-paleosoil sequences and river terrace formation). Földtani Közlöny 137, 515-540 (in Hungarian).

Gábris, Gy, 2011. A Zagyva-Tarna alföldi vízrendszerének kialakulása és fejlődése (Evolution of the Zagyva-Tarna river system on the Great Plain). Földrajzi Közlemények 135, 205-218 (in Hungarian).

Gábris, Gy, Félegyházi, E., Nagy, B., Ruszkiczay, Zs, 2001. A Középső-Tisza vidékének negyedidőszak végi folyóvízi felszínfejlődése (Late Quaternary evolution of the Middle Tisza Region)) (in Hungarian). In: I. MFK, Szeged, pp. 1-10.

Gábris, Gy, Horváth, E., Novothny, Á., Ruszkiczay-Rüdiger, Zs, 2012. Fluvial and aeolian landscape evolution in Hungary - results of the last 20 years research. Netherlands Journal of Geosciences 91, 111-128.

Gábris, Gy, Krolopp, E., Ujházy, K., 2011. Late Pleistocene (Late Glacial) - Holocene environmental changes along the Danube valley based on detailed complex examination of sand dune profiles. Földtani Közlöny 141, 57-72.

Gábris, Gy, Nádor, A., 2007. Long-term fluvial archives in Hungary: response of the Danube and Tisza rivers to tectonic movements and climatic changes during the Quaternary: a review and new synthesis. Quaternary Science Reviews 26, 2758-2782.

Gábris, Gy, Nagy, B., 2005. Climate and tectonically controlled river style changes on the Sajó-Hernád alluvial fan. In: Harvey, A.M., Mather, A.E. Stokes, M. (Eds.), Alluvial Fans. Geological Society, London, Special Publications 251, pp. 61-67.

Gábris, Gy, Túri, Z., 2008. Homokmozgás a történelmi időkben a Tiszazug területén Sand-moving periods in historic times near Tisza River). Földrajzi Közlemények 132, 241-250 (in Hungarian). 
Gulyás, S., Sümegi, P., 2011. Farming and/or foraging? New environmental data to the life and economic transformation of Late Neolithic tell communities in SE Hungary. Journal of Archaeological Science 38, 3323-3339.

Hernesz, P., Kiss, T., 2013. A Tisza meder partfalának vizsgálata: késő-pleisztocén és holocén folyóvízi folyamatok az Alsó-Tiszán (Late Pleistocene and Holocene development of the Lower Tisza). Hidrológiai Közlöny 93,13-19 (in Hungarian).

Horváth, F., 1993. Towards a mechanical model for the formation of the Pannonian basin. Tectonophysics 226, 333-357.

Horváth, F., Cloetingh, S., 1996. Stress induced late-stage subsidence anomalies in the Pannonian Basin. Tectonophysics 266, 287-300.

Jakab, G., Sümegi, P., Szántó, Zs, 2005. Késő-glaciális és holocén vízszintingadozások a Szigligeti-öbölben (Balaton) makrofosszília vizsgálatok eredményei alapján (Late Glacial and Holocene water level changes in the Szigliget Bay, Lake Balaton). Földtani Közlöny 135, 405-431 (in Hungarian).

Járainé-Komlódi, M., 1969. Adatok az Alföld negyedkori klíma-és vegetációtörténetéhez II (Quaternary vegetation history of the Great Hungarian Plain). Botanikai Közlemények 56, 43-55 (in Hungarian).

Járainé-Komlódi, M., 1997. A legutóbbi, azaz holocén beerdősülés flóratörténetébő Flora history of the Holocene). Botanikai Közlemények 84 (1-2), 3-15 (in Hungarian).

Járainé-Komlódi, M., 2000. A Kárpát-medence növényzetének kialakulása (Development of the vegetation of the Carpathian Basin). Tilia 9, 5-59 (in Hungarian).

Joó, I., 1992. Recent vertical surface movements in the Carpathian Basin. Tectonophysics 266, 287-300.

Juhász, Gy, Müller, P., Tóth-Makk, Á., 2004. Alluvial architecture and fluvial cycles in Quaternary deposits in a continental interior basin, E-Hungary. Geologia Croatica $57,171-190$.

Kasse, C., Bohncke, S.J.P., Vandenberghe, J., Gábris, Gy, 2010. Fluvial style changes during the last glacial-interglacial transition in the middle Tisza valley (Hungary). Proceedings of the Geologists' Association 121, 180-194.

Kasse, C., 2002. Sandy aeolian deposits and environments and their relation to climate during the Last Glacial Maximum and Lateglacial in northwest and central Europe. Progress in Physical Geography 26, 507-532.

Katona, O., Sipos, Gy, Nagy, Z, 2012a. A Maros hordalékkúp elhagyott medreinek hidromorfológiai és hidrodinamikai vizsgálata (Hydromorphology and hydrodynamics of the paleochannels of the Maros). In: VI. MFK, Szeged, pp. 1140-1150 (in Hungarian).

Katona, O., Sipos, Gy, Onaca, A., Ardelean, F., 2012b. Reconstruction of paleohydrology and fluvial architecture at the Orosháza paleo-channel of River Maros, Hungary. Journal of Environmental Geography 5, 29-38.

Kercsmár, Zs, Magyari, Á., Nádor, A., Unger, Z., Thamó-Bozsó, E., 2012. Tectonic control on changes in older quaternary sediment supply in the Körös sub-basin, and neotectonic movements in the eastern part of great Hungarian plain. In: Conference on Sustainable Development \& Ecological Footprint, Sopron, Hungary, pp. $1-5$.

Kiss, T., Blanka, V., Andrási, G., Hernesz, P., 2013. Extreme weather and the rivers of Hungary: rates of bank retreat. In: Lóczy, D. (Ed.), Geomorphological Impacts of Extreme Weather. Springer, Dordrecht, pp. 83-98.

Kiss, T., Hernesz, P., 2011. Az Alsó-Tisza-vidék árterének geomorfológiai jellegzetességei és kora (Geomorphological characteristics and floodplain development of the Lower Tisza Region, Hungary). Földrajzi Közlemények 135, 261-275 (in Hungarian).

Kiss, T., Hernesz, P., Sipos, Gy, 2012a. Meander cores on the floodplain - the early Holocene development of the low-floodplain along the Lower Tisza Region, Hungary. Journal of Environmental Geography 5, 1-10.

Kiss, T., Gy, Sipos, Mauz, B., Mezősi, G., 2012b. Holocene aeolian sand mobilization, vegetation history and human impact on the stabilized sand dune area of the southern Nyírség, Hungary. Quaternary Research 78, 492-501.

Kiss, T., Nyári, D., Sipos, Gy, 2008. Történelmi idők eolikus tevékenységének vizsgálata (Aeolian activity in historical times). In: Szabó, J., Demeter, G. (Eds.), Tanulmányok Kádár László 100. születésnapjára. Debrecen: Kosssuth Egyetemi Kiadó, pp. 99-106 (in Hungarian).

Kiss, T., Sümeghy, B., Sipos, Gy, 2014. Late Quaternary paleodrainage reconstruction of the Maros River alluvial fan. Geomorphology 209, 49-60.

Láng, S., 1960. A Délkelet-Alföld felszíne (The Southeast Great Plain). Földrajzi Közlemények 84, 31-43 (in Hungarian).

Lóki, J., 2012. A nyírségi futóhomokformák átalakulása (Blown sand development of the Nyírség). In: VI. MFK, Szeged, pp. 549-564 (in Hungarian).

Lóki, J. Hertelendi, E., Borsy, Z., 1994. New dating of blown sand movement in the Nyírség. Acta Geographica ac Geologica et Meteorologica Debrecina 32, 67-76.

Lóki, J., Sümegi, P., Félegyházi, E., Hertelendi, E., 1995. A Kolon-tó fenékszintjébe mélyített fúrás rétegsorának szedimentológiai, pollenanalitikai és malakofaunisztikai elemzése (Sedimentological, pollen analytical and malakofaunistic studies of the Lake Kolon). Acta Geographica ac Geologica et Meteorologica Debrecina 33, 93-115.

Lovász, Gy, 2002. A holocén felszínfejlődési folyamatok rekonstrukciója Magyarországon (Landscape development of Hungary during the Holocene). Földrajz Értesítö 51, 31-39 (in Hungarian).

Magyar, I., Geary, D., Müller, P., 1999. Paleogeographic evolution of the Late Miocene Lake Pannon in Central Europe. Palaeogeography, Palaeoclimatology, Palaeoecology $147,151-167$

Markovic, S.B., Bokhorst, M.P., Vandenberghe, J., McCoy, W.D., Oches, E.A. Hambach, U. Gaudenyi, T. Jovanovic, M., Zöller, L., Stevens, T., Machalett, B. 2008. Late Pleistocene loess-palaeosol sequences in the Vojvodina region, north Serbia. Journal of Quaternary Science 23/1, 73-84.
Mezősi, G., 1983. Szeged geomorfológiai vázlata (Geomorphology of Szeged). Alföldi Tanulmányok 7, 59-74 (in Hungarian).

Mezősi, G., 2011. Magyarország természetföldrajza (Physical Geography of Hungary). Akadémia Kiadó, Budapest, pp. 108-117.

Miháltz, I., 1967. A Dél-Alföld felszínközeli rétegeinek földtana (Geology of Southern Hungary). Földtani Közlemények 97, 294-307 (in Hungarian).

Mike, K., 1991. Magyarország ősvízrajza és felszíni vizeinek története (Paleohydrology of Hungary). Aqua, Budapest (in Hungarian).

Nádor, A., Lantos, M., Tóth-Makk, A., Thamó-Bozsó, E., 2003. Milankovitch-scale multi-proxy records for the fluvial sediments of the last 2.6 Ma from the Pannonian Basin, Hungary. Quaternary Science Reviews 22, 2157-2175.

Nádor, A., Sinha, R., Magyari, A., Tandon, S.K., Medzihradszky, Zs, Babinszki, E., Thamó-Bozsó, E. Unger, Z., Singh, A., 2011. Late Quaternary (Weichselian) alluvial history and neotectonic control on fluvial landscape development in the southern Körös plain, Hungary. Palaeogeography, Palaeoclimatology, Palaeoecology 299, 1-14.

Nádor, A., Thamó-Bozsó, E., Magyari, Á., Babinszki, E., 2007. Fluvial responses to tectonics and climate change during the Late Weichselian in the eastern part of the Pannonian Basin (Hungary). Sedimentary Geology 202, 174-192.

Nádor, A., Thamó-Bozsó, E., Magyari, Á., Babinszki, E. Dudko, A., Tóth, Z., 2005 Neotektonika és klímaváltozás együttes hatása a Körös-medence későpleisztocén vízhálózat-fejlődésére (The effect of neotectonism and climate change on the development of the Körös basin). MÁFI Évi Jelentése, Budapest, pp. 131-148 (in Hungarian).

Nagy, B., 2002. A felszínfejlődés késő-pleisztocén-holocén jellegzetességei a SajóHernád hordalékkúpon (Late Pleistocene-Holocene evolution of the Sajó-Hernád alluvial fan). Földtani Közlöny 132, 93-100 (in Hungarian).

Nagy, B., Félegyházi, E., 2001. A Sajó-Hernád hordalékkúp későpleisztocén mederhálózatának vizsgálata (Investigation of the Late Pleistocene channel pattern of Sajó-Hernád alluvial fan). Acta Geographica ac Geologica et Meteorologica Debrecina 35, 221-232 (in Hungarian).

Nováky, B., 1991. Climatic effects on runoff conditions in Hungary. Earth Surface Processes and Landforms 7, 593-600.

Novothny, Á., Frechen, M., Horváth, E, 2010. Luminescence dating of sand movement periods from the Gödöllö Hills, Hungary. Geomorphology 122, 254-263.

Pécsi, M., 1959. A magyarországi Duna-völgy kialakulása és felszínalaktana (Development and geomorhology of the Hungarian Danube valley). Akadémiai Kiadó, Budapest, p. 346 (in Hungarian).

Pécsi, M., 1970. Surfaces of planation in the Hungarian mountains and their relevance to pedimentation. In: Pécsi, M. (Ed.), Problems of Relief Planation. Akadémiai Kiadó, Budapest, pp. 29-40.

Pécsi, M., 1975. Stratigraphical subdivision of the Hungarian loess sections. Földrajzi Közlemények 23, 217-230.

Pécsi, M., 1993. Negyedkor és löszkutatás (Quaternary and loess). Akadémiai Kiadó, Budapest (in Hungarian).

Pécsi, M., 1996. Geomorphological Regions of Hungary. Studies in Geography in Hungary. MTA-FKI, Budapest, 28.

Petrovszki, J., Timár, G., 2010. Channel sinuosity of the Körös River system, Hungary/ Romania, as possible indicator of the neotectonic activity. Geomorphology 122, 223-230.

Pinczés, Z. 1983. A krioplanációs meredek lejtő kialakulása és morfológiája (Development and morphology of crioplanation slopes). Földrajzi Értesítő 32, 461-473 (in Hungarian).

Pinczés, Z., Martonné Erdős, K., Dobos, A., 1993. Eltérések és hasonlóságok a hegylábfelszínek pleisztocén felszínfejlödésében (Similarities and differences in the development of planation surfaces). Földrajzi Közlemények 117, 149-162 (in Hungarian).

Popov, D., Marković, S.B., Štrbac, D., 2008. Generations of meanders in Serbian part of Tisa valley. In: Geogr. Insit. "Jovan Cvijic" Sasa Collection of Papers 58, pp. 29-42.

Rachocki, A., 1981. Alluvial Fans: an Attempt at an Empirical Approach. Wiley, Chichester, 161.

Rasmussen, S.O., Andersen, K., Svensson, A., Steffensen, J., Vinther, B., Clausen, H. Siggaard-Andersen, M., Johnsen, S., Larsen, L., Dahl-Jensen, D., Bigler, M., Röthlisberger, R., Fischer, H., Goto-Azuma, K., Hansson, M., Ruth, U., 2006. A new Greenland ice core chronology for the last glacial termination. Journal of Geophysical Research 111, D6.

Rónai, A., 1985. Az Alföld negyedidőszaki földtana (Quaternary Geology of the Great Hungarian Plain). Geologica Hungarica, Series Geologica 21 (in Hungarian).

Rotnicki, K. 1991. Retrodiction of palaeodischarges of meandering and sinuous alluvial river and its palaeohydroclimatic implications. In: Starkel, L., Gregory, K.J., Thornes, J.B. (Eds.), Temperate Palaeohydrology. Wiley \& Sons, Chichester pp. $431-471$.

Ruszkiczay-Rüdiger, Zs, Braucher, R., Csillag, G., Fodor, L., Dunai, T.J., Bada, G., Bourlès, D., Müller, P., 2011. Dating Pleistocene aeolian landforms in Hungary, Central Europe, using in situ produced cosmogenic ${ }^{10} \mathrm{Be}$. Quaternary Geochronology 6, 515-529.

Schumm, S.A., 1985. Patterns of alluvial rivers. Annual Review of Earth Planetary Science 13, 5-27.

Sipos, Gy, Kiss, T., Koroknai, L., Horváth, Zs, Dezső, J., 2010. Late Pleistocene-Early Holocene climatic shift recorded by the paleomorphology of the Lower Tisza fluvial system, Hungary. In: Proceedings of EGU-Wien 12. EGU2010-1001.

Somogyi, S., 1961. Hazánk folyóhálózatának fejlődéstörténeti vázlata (Development of the Hungarian fluvial system). Földrajzi Közlemények 9, 25-50 (in Hungarian).

Somogyi, S., 1967. Ösföldrajzi és morfológiai kérdések az Alföldröl (Paleo-hydrography of the Great Plain). Földrajzi Értesítő 16, 319-337 (in Hungarian). 
Starkel, L., 2002. Younger Dryas-Preboreal transition documented in the fluvial environment of Polish rivers. Global and Planetary Change 35, 157-167.

Sümeghy, B., Kiss, T., 2011. Discharge calculation of paleochannels on the alluvial fan of the Maros River, Hungary. Journal of Environmental Geography 4, 11-17.

Sümeghy, B., Kiss, T., 2012. Morphological and hydrological characteristics of paleochannels on the alluvial fan of the Maros River, Hungary. Journal of Environmental Geography 5, 11-19.

Sümeghy, B., Kiss, T., Sipos, Gy, Tóth, O., 2013. A Maros hordalékkúp későpleisztocén-holocén fluviális képződményei (Late Pleistocene-Holocene fluvial forms of the Maros alluvial fan). Földtani Közlöny 143, 445-468 (in Hungarian).

Sümegi, P., 2004. Environmental changes under the neolithization process in Central Europe: before and after. In: Antaeus. Comm. Inst. Archaeo. MTA 27, pp. 117-127.

Sümegi, P., Juhász, I., Magyari, E., Jakab, G., Rudner, E., Szántó, Zs, Molnár, M., 2008. A keleméri Mohos-tavak fejlődéstörténetének rekonstrukciója paleobotanikai vizsgálatok alapján (The development of the Mohos Lakes near Kelemér). ANP füzetek 4, 35-57 (in Hungarian).

Sümegi, P., Krolopp, E., 1995. A magyaroszági würm korú löszök képződésének paleoökológiai rekonstrukciója Mollusca-fauna alapján (Paleoecological reconstruction of Würmian loesses based on Mollusca fauna). Földtani Közlöny 125, 125-148 (in Hungarian).

Sümegi, P., Krolopp, E., Hertelendi, E., 1998. A Ságvár-Lascaux interstadiális paleoökológiai rekonstrukciója (Paleoecological reconstruction of the Ságvár-Lascaux Interstadial). Acta Geographica ac Geologica et Meteorologica Debrecina 34, 165-180 (in Hungarian).

Sümegi, P., Krolopp, E., Rudner, E., 2002. Negyedidőszak végi őskörnyezeti változások a Kárpát-medencében térben és időben (Late Quaternary environmental changes in the Carpathian Basin). Földtani Közlöny 132, 5-22 (in Hungarian).

Sümegi, P., Törőcsik, T., 2007. Hazánk növényzete az éghajlatváltozások tükrében (Vegetation history and climate change). Természet Világa 138, 1-9 (in Hungarian).

Szabó, J., Vass, R., Tóth, Cs, 2012. Examination of fluvial development on study areas of Upper-Tisza region. Carpathian Journal of Earth and Environmental Science $7 / 4,241-253$.

Székely, A., 1977. Periglaciális domborzatalakulás a magyar középhegységekben (Periglacial landform evolution in the Hungarian mountain ranges). Földrajzi Közlemények 101, 46-59.
Szöör, Gy, Sümegi, P., Hertelendi, E., 1989. Őshőmérsékleti adatok meghatározása malakohőmérő-módszerrel az Alföld felső pleisztocén - holocén klímaváltozásaival kapcsolatban (Late Pleistocene-Holocene temperature reconstruction based on malacological results). Acta Geographica ac Geologica et Meteorologica Debrecina 28-29, 217-229 (in Hungarian).

Thamó-Bozsó, E., Csillag, G., Fodor, L.I., Müller, P.M., Nagy, A., 2010. OSL-dating the Quaternary landscape evolution in the Vértes Hills forelands (Hungary). Quaternary Geochronology 5, 120-124.

Thamó-Bozsó, E., Magyari, A., Nagy, A., Unger, Z., Kercsmár, Zs, 2007. OSL dates and heavy mineral analysis of Upper Quaternary sediments from the valleys of the Ér and Berettyó Rivers. Geochronometria 28, 17-23.

Timár, G., 2003. Geológiai folyamatok hatása a Tisza alföldi szakaszának medermorfológiájára (The effects of geological processes on the channel planform of the Tisza River, the Great Hungarian Plain) (PhD thesis). ELTE, Budapest, 135. (in Hungarian).

Timár, G., Gábris, Gy, 2008. Estimation of water conductivity of natural flood channels on the Tisza flood-plain, the Great Hungarian Plan. Geomorphology 98, 250-261.

Timár, G., Sümegi, P., Horváth, F., 2005. Late Quaternary dynamics of the Tisza River: evidence of climatic and tectonic controls. Tectonophysics 410, 97-110.

Ujházy, K., Gábris, Gy, Frechen, M., 2003. Ages of periods of sand movement in Hungary determined through luminescence measurements. Quaternary International 111, 91-100.

Vágás, I., 1982. A Tisza árvizei (Floods of the Tisza). VIZDOK, Budapest, 283.

Vass, R., Szabó, G., 2008. A mátyusi eróziós sziget homoküledékeinek binokuláris mikroszkópos vizsgálata (Sedimentological study of an erosional island). In Szabó, J., Demeter, G. (Eds.), Tanulmányok a Kádár László születésének 100. évfordulóján. Kossuth Egyetemi Kiadó, Debrecen, pp. 161-168 (in Hungarian).

Vörös, I., 1987. Large mammalian faunal changes during the Late Upper Pleistocene and Early Holocene times in the Carpathian Basin. In: Pécsi, M. (Ed.), Pleistocene Environment in Hungary. MTA-FKI, Budapest, pp. 81-103.

Williams, G.P., 1984. Paleohydrological equations for rivers. In: Costa, J.E. Fleisher, P.J. (Eds.), Developments and Applications of Geomorphology. Springer, Berlin, pp. 343-367.

Willis, K.J. Van Andel, T.H. 2004. Trees or no trees? The environments of central and eastern Europe during the Last Glaciation. Quaternary Science Reviews 23, 2369-2387.

Willis, K.J., Rudner, E., Sümegi, P., 2000. The full-glacial forests of central and southeastern Europe. Quaternary Research 53, 203-213. 